\title{
Chlorophyll Response to Shelf-Break Upwelling and Winds in the Chukchi Sea, Alaska, in Autumn
}

\author{
John P. Christensen ${ }^{1, *}$, Koji Shimada ${ }^{2}$, Igor Semiletov ${ }^{3}$ and Patricia A. Wheeler ${ }^{4}$
}

${ }^{1}$ Bigelow Laboratory for Ocean Sciences, 180 McKown Point, West Boothbay Harbor ME 04575 USA; ${ }^{2}$ Ocean Re-
search Dept., Japan Marine Science \& Technology Center, 2-15 Natsushima, Yokosuka 237 Japan; ${ }^{3}$ International Arctic
Research Center, University of Alaska at Fairbanks, Fairbanks, AK, 99775-7340 USA and ${ }^{4}$ College of Oceanic and At-
mospheric Sciences, Ocean Administration Bldg 104, Oregon State University, Corvallis OR 97331 , USA

Abstract: In the Chukchi Sea, autumn 1996 was windier than most of the previous 35 years. Conditions in the Bering Strait were anomalous, with fresh coastal water absent from the Strait and a partial flow reversal apparently occurring. In the central Chukchi Sea, the northeastward flow of the Alaskan Coastal Current was reversed. In the northern Chukchi Sea, upwelling of offshore, high-nutrient upper halocline waters inundated much of the shelf near Barrow Canyon. The resulting chlorophyll blooms indicate dramatically enhanced ecosystem productivity along this northern shelf region. With increasing climatic change occurring in this region, shelf break productivity would likely increase in the future.

\section{INTRODUCTION}

Approximately $0.8 \mathrm{~Sv}\left(1 \mathrm{~Sv}=10^{6} \mathrm{~m}^{3} / \mathrm{s}\right)$ of sea water passes northward through the Bering Strait, crosses the Chukchi Sea continental shelf, and enters into the Canadian Basin and Beaufort Seas [1]. The flow through the Strait is composed of two water types. Those upwelled near the Gulf of Anadyr in the northern Bering Sea are salty and nutrient rich, and those flowing northward along the Alaskan coast are strongly influenced by the Yukon River [2, 3]. As a result of the high nutrient concentrations and the intense mixing of waters within the Strait, algal productivity in the region north of the Strait is high (300 $\mathrm{g} \mathrm{C} \mathrm{m}^{-2} \mathrm{y}^{-1}$ [4-6]). Because the shelf is wide (approximately $800 \mathrm{~km}$ from the Strait to the $200 \mathrm{~m}$ isobath) and the area influenced by the Bering Strait is large $\left(300,000 \mathrm{~km}^{2}\right)$, the average volumetric residence time on the shelf is about 1 y [1,7], although the pathways and transit times of the Bering Strait water types differ. The remnants of the denser Anadyr water sink and follow the longer topographic depression (Hope Valley and Herald Canyon) northwest from Bering Strait, potentially exiting the shelf near Wrangel Island [1]. A middle pathway between Herald Canyon and the Alaskan Coastal Current has been recently proposed $[8,9]$, but the flow in this pathway is weak and may simply reflect the overall net northward drift $[7,10]$. With a transit time of several months in summer, the Alaskan Coastal Current follows the northwest Alaskan coast and enters the offshore Canada Basin in the vicinity of Point Barrow [1, 11]. By the time the Alaskan waters reach the Barrow region, inorganic nitrogen nutrients have disappeared from the water column and plant productivity is thought to be very low (40 $\mathrm{g} \mathrm{C} \mathrm{m}^{-2} \mathrm{y}^{-1}$ [12-14]).

This normal circulation may be interrupted by the strong northeasterly winds occurring in the autumn, and three char-

*Address correspondence to this author at the Bigelow Laboratory for Ocean Sciences, 180 McKown Point, West Boothbay Harbor ME 04575 USA; E-mail: jchristensen@bigelow.org acteristic physical responses have been observed. Winds blowing south near the Bering Strait may cause partial flow reversals in the Strait and may alter the circulation south of the Strait [2, 15-18]. Along the northwest Alaskan coast, winds blowing from the northeast may block and reverse the Alaskan Coastal Current [11, 19, 20]. Within Barrow Canyon, upwelling of deeper offshore water may partially correlate with these same winds [11, 20, 21]. Additional upwelling has been noted east of Barrow Canyon, on the narrow shelves of the Beaufort Sea and eastern portion of the Chukchi Sea [22, 23]. Most reports of northern Alaskan shelfslope upwelling have focused on physical and hydrographic issues, but no study has examined the impact these events have on productivity. In an oligotrophic ecosystem, upwelling of nutrient rich water would be expected to measurably enhance productivity and abundances. Although upwelling has been mentioned as a possible cause of potentially richer euphotic zone conditions [14, 24-26], most recent studies have either occurred in the less-windy summer season or were conducted with sampling strategies that were too infrequent in space and time to evaluate details of possible upwelling events [13, 14, 24, 26, 27].

In this report, we examine the hydrographic, nutrient, and chlorophyll conditions found in the Chukchi Sea in the early fall of 1996. We first show that winds during this period were stronger than during most of the years of 1960-1995, so that affects of these winds would be expected to be more intense than normally found. Secondly we show evidence that the three hydrographic conditions associated with high winds did occur. Finally, we show that intense nutrient upwelling dramatically altered the inventory and distribution of chlorophyll in the northern Alaskan marine ecosystem.

\section{MATERIALS AND METHODS}

Hydrographic, nutrient, and chlorophyll measurements, acoustic doupler current profiler (ADCP) current measure- 
ments, and meteorological observations were made in the Chukchi Sea from the R.V. Alpha Helix between August 31 - September 28 (Julian days 244-272), 1996 (Fig. 1). Individual stations were located along transect lines. Where transect lines were repeated, the line numbers are distinguished by the suffixes, a and b, for the first and second samplings, respectively.

In order to characterize the relative intensity of the winds during the time of this cruise, long-term average winds were calculated from hourly Point Barrow airport data (Solar and Meteorological Surface Observation Network, 1961-1990, Hourly United States Weather Observations, 1990-1995, and hourly data from 1996). Upwelling intensity was evaluated based on the Bakun index [28], which represents the depthintegrated Ekman transport $\left.\left(\mathrm{m}^{3} \mathrm{~s}^{-1} \text { ( } \mathrm{m} \text { of coastline) }\right)^{-1}\right)$ perpendicular to an ideal wind oriented in the same direction as the coastline. Since shipboard operations focused on the re- gion just west of Point Barrow, the Bakun index [28] used the average orientation of the coast line between Point Barrow and Cape Lisburne ( $241^{\circ}$ true). For the long-term Barrow data, averages over every 0 to 24 hour period within each year were calculated. The thirty-five year mean for each Julian day was then computed. Additional weather data were collected on the R/V Alpha Helix at approximately 2 minute intervals. For these data and the 1996 Barrow hourly data, four-hour averages were calculated and the Bakun index computed.

During shipboard operations, over 200 continuous profiles of conductivity, temperature, pressure, light transmission, in situ fluorescence, and oxygen were made from the sea surface to the seafloor using the ship's Seabird CTD and Rosette system (Fig. 1). The downcast data was averaged over 1 dbar intervals, and Niskin bottles were tripped on the upcast. Salinities from bottle samples deeper than $100 \mathrm{~m}$

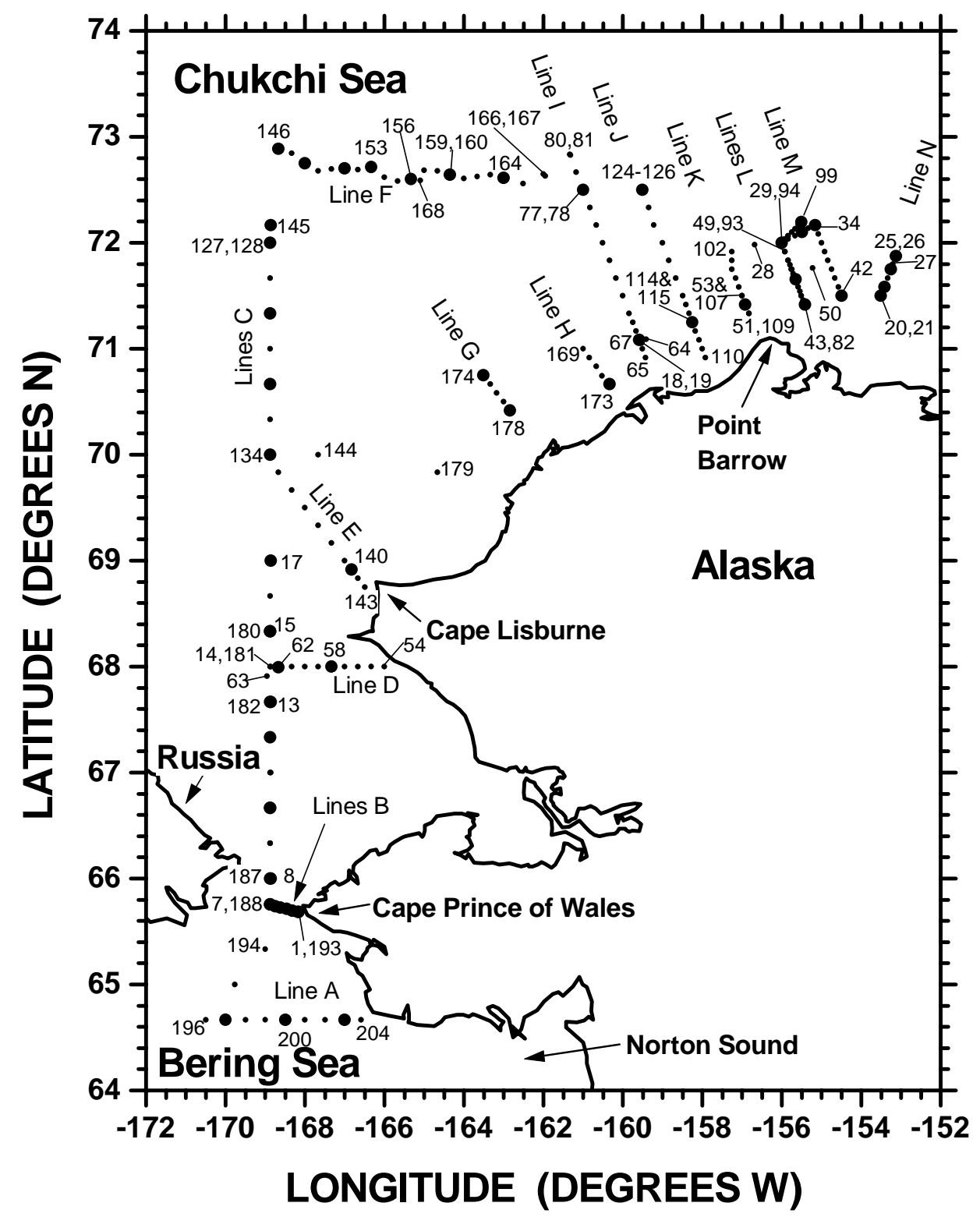

Fig. (1). Locations of CTD casts made in the Chukchi Sea between Julian days 244-272 (August 31-September 28), 1996. Small circles represent stations with CTD sensors only. Large circles are stations with additional water samples for nutrients and chlorophyll. Cast numbers are next to the circles. 
were analyzed using an Autosal salinometer referenced against IAPSO standard sea water, and the CTD results corrected to average bottle results [29]. Nutrient samples were frozen and measured by autoanalyzer on shore [30]. We report on the silicate concentrations and the sum of the nitrate and nitrite concentrations. Nitrite concentrations were generally less than $0.3 \mu \mathrm{M}$. Chlorophyll-a concentrations were determined by filtration of Niskin water samples through 47 $\mathrm{mm}$ GFF glass fiber filters and by fluorometric measurement after calibration with pure chlorophyll-a standards [30]. A close linear relationship was found between in situ fluorescence and the bottle determinations $\left(r^{2}=0.909, n=279\right)$, allowing the conversion of the continuous profiles to profiles of chlorophyll-a concentration. No statistically significant difference was seen in the regressions between fluorescence and chlorophyll concentrations for samples collected during the day versus those collected at night. Here, we note that section graphs were drawn based on the CTD data [29] collected along the transect lines that took as long as 40 hours to complete. Differences in vertical heights along each transect due solely to tidal changes would be relatively small since diurnal constituents, $\mathrm{O}_{1}$ and $\mathrm{K}_{1}$, had maximum surface amplitudes for all Chukchi shelf and slope regions of less than 5 $\mathrm{cm}[31,32]$. Unfortunately, the time required for transects may be sufficiently slow so that in dynamic areas, such as the Bering Strait or Barrow Canyon, the distributions may change more rapidly than the speed of transit and sample collection, but this is a common difficulty for all ship-based oceanographic programs.

Current velocities were measured during two minute ensembles of the $300 \mathrm{kHz}$ shipboard ADCP system operating in bottom tracking mode. All results were taken when the ship's speed was greater than $200 \mathrm{~cm} / \mathrm{s}$ and when the quality of returning acoustic signals were $85 \%$ or greater. Results were binned into $4 \mathrm{~m}$ depth intervals below the surface. The $14 \mathrm{~m}$ bin was the shallowest bin with the greatest number of high quality sonic returns. Bias and alignment errors were determined following [33]. Additional details about this shipboard system may be obtained in literature containing previous years' results [8,34].

\section{RESULTS}

We first evaluated the wind conditions at Point Barrow in order (a) to determine the seasonality based on the 35 year history, and (b) to evaluate whether 1996 was an unusual year. Following this, we describe the distributions of waters based on the CTD transect lines, nutrients and chlorophyll concentrations. We show changes in conditions within the Bering Strait and in the Alaska Coastal Current, and examine an upwelling event on the northern shelf break. Finally, we examine the relationship of nutrients and chlorophyll to the distribution of upwelled offshore waters.

\section{Meteorological Observations}

Long-term mean weather conditions were calculated for Point Barrow airport based on the 1961-1995 hourly weather data averaged over $24 \mathrm{hr}$ periods (Fig. 2). The seasonal air temperature showed the highest daily temperatures (about $4^{\circ}$ C) during the 60 days centered on Julian day 210, while in contrast, air pressure showed a period of lowest pressures extending from this temperature maximum through day 300
(Fig. 2). As a long-term mean, wind direction was relatively constant throughout the year, with winds coming from $60-90^{\circ}$ true (Fig. 2). Although wind speed was moderately variable, the early fall period showed stronger winds than found either in summer or in the early winter (Fig. 2). The average over the fall (Julian day 250 through 320$)$ was $5.29 \mathrm{~m} / \mathrm{s}(95 \%$ confidence interval $=+/-0.094 \mathrm{~m} / \mathrm{s}$ ) relative to the average for the combined periods of summer (Julian day 160-240) and early winter $(330-365)$ of $4.53 \mathrm{~m} / \mathrm{s}(95 \%$ c.i. $=0.064$ $\mathrm{m} / \mathrm{s})$.

The strength of wind-driven coastal upwelling was estimated via the Bakun index based on the wind speed and direction relative to the direction of the coastline between Cape Lisburne and Point Barrow. The numerical value of this index is the Ekman transport, the volume rate of upwelling per $\mathrm{m}$ length of coastline. Based on the 35-year wind record, the average winds were supportive of upwelling throughout the year (Fig. 2). The lack of negative indices indicates no season with consistent downwelling along the northwest Alaska coastline. Potential upwelling activity was $61 \%$ greater during the fall period than in the periods before and after (Fig. 2). The average for the fall period (Julian day 250-320) was $0.18 \mathrm{~m}^{3} \mathrm{~s}^{-1} \mathrm{~m}^{-1}\left(95 \%\right.$ c.i. $\left.=0.019 \mathrm{~m}^{3} \mathrm{~s}^{-1} \mathrm{~m}^{-1}\right)$ while the combined periods before and after had an average of $0.11 \mathrm{~m}^{3}$ $\mathrm{s}^{-1} \mathrm{~m}^{-1}\left(95 \%\right.$ c.i. $\left.=0.011 \mathrm{~m}^{3} \mathrm{~s}^{-1} \mathrm{~m}^{-1}\right)$.

We examined the weather record for the 1996 period around the cruise dates, Julian days 214-280 (Fig. 3). Barometric pressure, wind speed and direction, and Bakun index from the shipboard measurements compared quite closely with those from Point Barrow data record (only shipboard pressure is shown in Fig. 3). Seven low pressure events occurred while the ship was nearing or in the Chukchi Sea (between Julian days of 242 and 271), and these events were also recorded at Point Barrow (Julian day 243-274). Storms showed augmented wind speeds frequently exceeding 10 $\mathrm{m} / \mathrm{s}$. Five of the seven storms resulted in a significant increase in the Ekman transport (the Bakun index). In these five storms associated with increased upwelling, the winds at Barrow were directed out of the east (60-120 ${ }^{\circ}$ true). In the two storms that showed no change in the upwelling index, winds were directed out of the north (330-30 ${ }^{\circ}$ true).

The entire period of August to October, can be divided in periods of consistent upwelling and downwelling (Fig. 3). For the early period between Julian days 215-232, the winds maintained episodically strong downwelling. After Julian day 232, three multiple-day periods of strong upwelling occurred during the cruise, many with Bakun indices exceeding $1.0 \mathrm{~m}^{3} \mathrm{~s}^{-1} \mathrm{~m}^{-1}$. Each upwelling period is best characterized by the wind direction shifting to a course nearly parallel to the coast between Cape Lisburne and Point Barrow. In the third upwelling period (Julian day 258-271), the mean Bakun index was $0.53 \mathrm{~m}^{3} \mathrm{~s}^{-1} \mathrm{~m}^{-1}(+/-0.087,95 \%$ c.i. $)$. Between upwelling periods, two 6-day long periods occurred (Julian days 235-241 and 252-258) where winds supported either upwelling-neutral or downwelling conditions. For the later quiescent period (Julian day 252-258) the mean Bakun index was $-0.057 \mathrm{~m}^{3} \mathrm{~s}^{-1} \mathrm{~m}^{-1}$ (+/- $0.021,95 \%$ c.i. $)$.

We examined the relative strength of upwelling-inducing winds during our sampling in 1996 versus the earlier 35 years (Fig. 4). For this, the Ekman transports were averaged between days 250-270 for each year, essentially covering the 


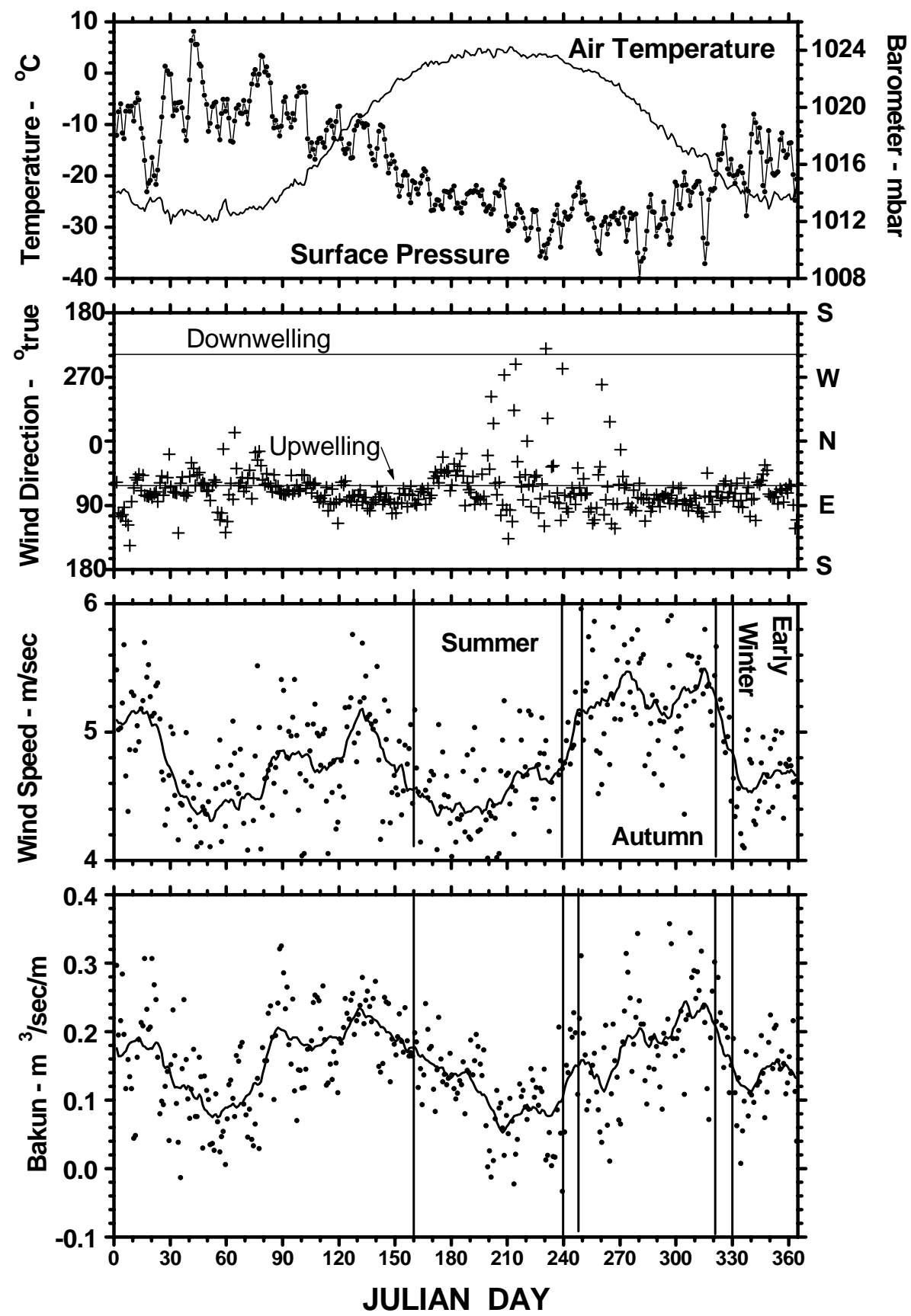

Fig. (2). Average atmospheric pressure, temperature, wind direction, wind speed and Bakun index from Barrow airport weather records over 35 years (1961-1995). Data are 24-hour averages. The thin horizontal lines in the wind direction panel represent the wind direction for maximal upwelling and maximal downwelling for the $241^{\circ}$ coastline. Thick lines on wind speed and Bakun index are the smoothed trends based on centered running means. Stronger winds generally occur in the fall (Julian days 250-320) relative to less windy periods in summer and early winter (Julian days 160-240 and 330-365).

period of our cruise (Fig. 4 top). In 1996, this average transport was $0.36 \mathrm{~m}^{3} \mathrm{~s}^{-1} \mathrm{~m}^{-1}$ and was the sixth highest year since 1961. This ranking shows that the year of our cruise was exceptional in the wind-driven upwelling along the northwest Alaskan coast. However, the estimate may have bias since coastal upwelling typically requires about a day of wind stress before water motions approach equilibrium. We employed another statistic where, for Julian days 250-320, a storm was considered to be an event where Ekman transport exceeded the 35 year average $\left(0.18 \mathrm{~m}^{3} \mathrm{~s}^{-1} \mathrm{~m}^{-1}\right)$ for 3 days or more. We summed the number of days in these storms and normalized to 70 day total time. In 1996, $40 \%$ of the days were stormy. A plot of this percentage of stormy days for each year showed that 1996 ranked 9th of the 36 years of data (Fig. 4 bottom). Both of these analyses indicate that wind-driven coastal upwelling in September 1996 was strong relative to the preceding 35 years. We now describe the significant changes in hydrographic conditions that occurred between the beginning and end of the ship board operations. 

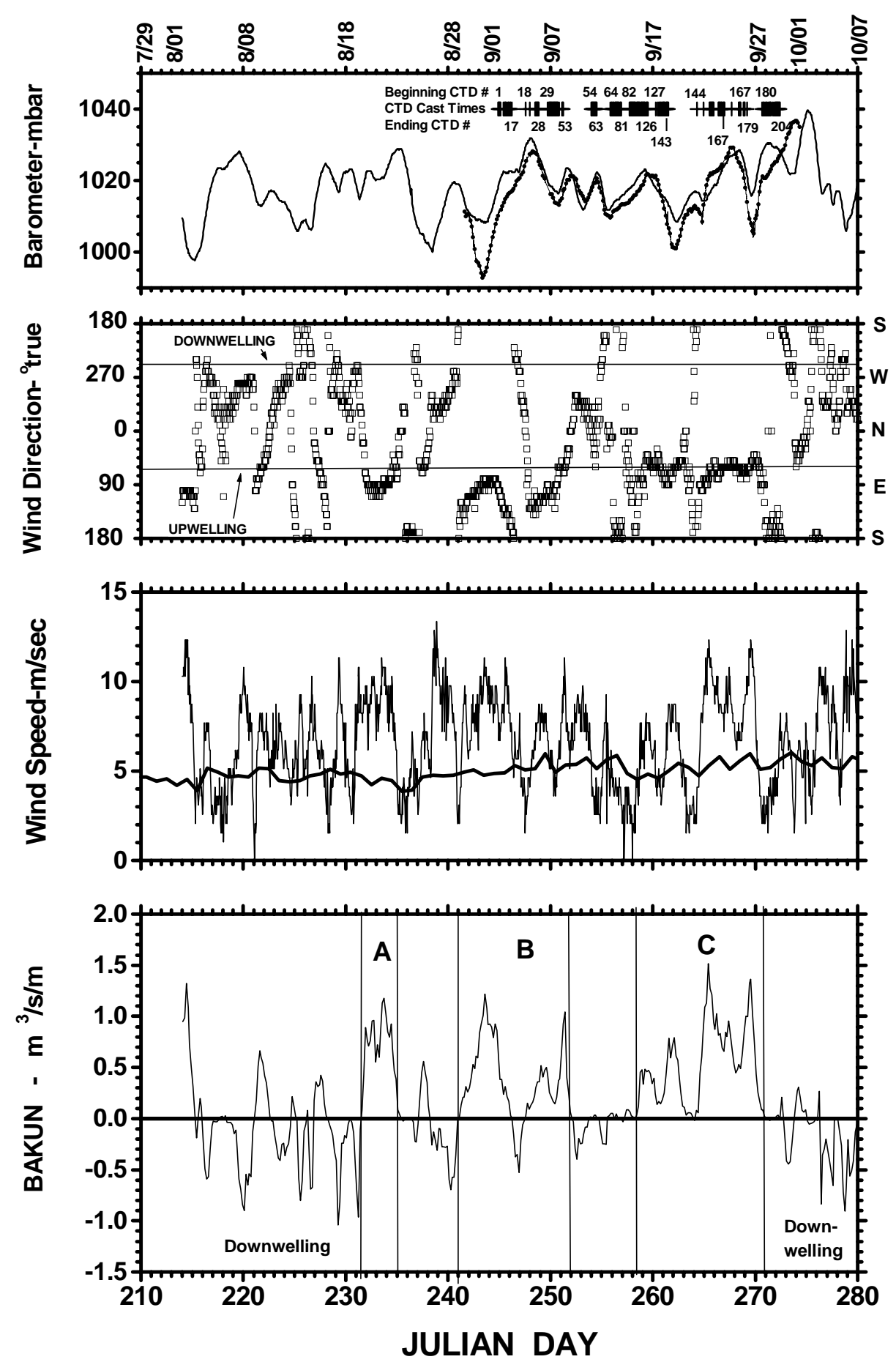

Fig. (3). Atmospheric pressure, wind speed, wind direction, and Bakun upwelling index for Julian days 214-280 (late July - October 8) 1996 as measured at Point Barrow airport and on the R.V. Alpha Helix (4 hour averages for both). The thin solid lines and open squares represent Barrow data; while the closed circles are shipboard measurements. The times of the CTD casts are shown as crosses on the upper panel. Wind direction for maximal upwelling and downwelling along the coast between Cape Lisburne and Point Barrow are shown as horizontal lines in the wind direction panel. The heavy wind-speed line is the climatological mean for Julian days 210-280. The Bakun index showed that the period was divided into discrete periods of upwelling and downwelling.

\section{HYDROGRAPHIC OBSERVATIONS}

\section{Bering Strait}

We obtained two sets of observations from the Bering Strait region, one at the beginning of the cruise (Julian days 244-246, CTD 1-17) and one on day 271 (Fig. 1). On days
244-246, two waters types were found within the Bering Strait, warm fresher $\left(>8.5^{\circ} \mathrm{C}\right.$, salinities <31) waters on the eastern side of the Strait and cooler more-saline water $\left(<7^{\circ} \mathrm{C}\right.$, 31.7 salinity) on the western portion of the U.S. Strait (Fig. 5). The fresher waters had sigma-t values of $<23.4 \mathrm{~kg} / \mathrm{m}^{3}$ while the more saline water had sigma-t values of $>24.8$ 

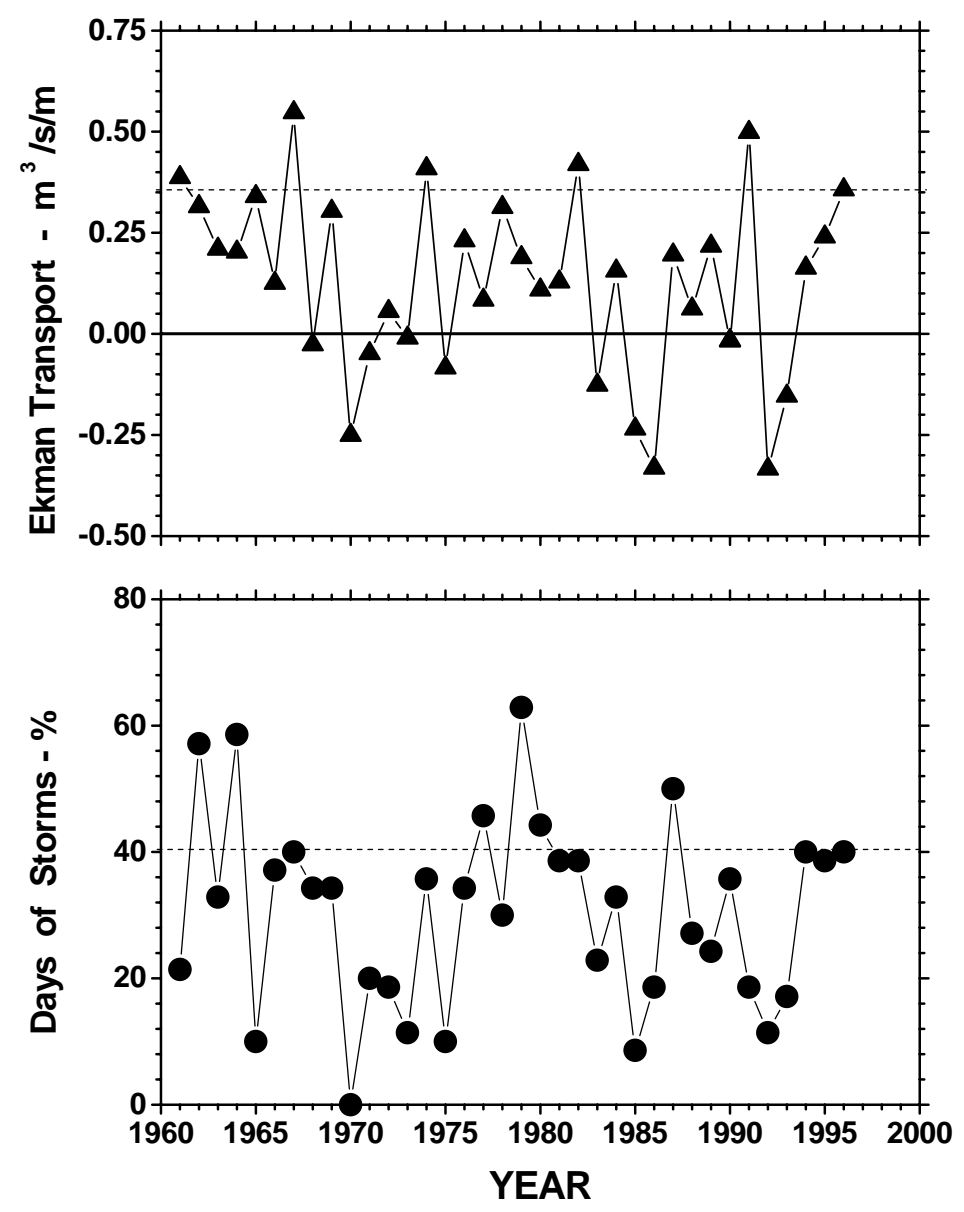

Fig. (4). TOP: The average Ekman transport for Julian days 250-270 for all years from 1961 through 1996. BOTTOM: Percent of storm days occurring between Julian days 250 and 320 for all years from 1961 through 1996. A storm is a period of 3 days or more when the Ekman transport exceeds the average for all years $\left(0.18 \mathrm{~m}^{3} \mathrm{~s}^{-1} \mathrm{~m}^{-1}\right)$. The percent storm days is the sum of the days which occurred within storms divided by the total days in the time period. Ekman transport was based on 24 hour averages of the Barrow winds. Horizontal dotted lines mark the 1996 levels.

$\mathrm{kg} / \mathrm{m}^{3}$. The fresher end-member represented the typical latesummer waters of the Alaskan coast which is influenced by the Yukon River; while those waters on the U.S. Russian border were a mix of coastal water and Pacific waters upwelled from the Gulf of Anadyr. Waters just north of the Strait, at depth in CTDs 13-16, were cooler and saltier $\left(<3.5^{\circ}\right.$ C, salinity of 32.4 , and $>25.8 \mathrm{~kg} / \mathrm{m}^{3}$ ) were typical of latesummer Anadyr Water. Silicate and nitrate plus nitrite concentrations of the Anadyr water were about $38 \mu \mathrm{mol}-\mathrm{Si} / \mathrm{L}$ and $18 \mu \mathrm{mol}-\mathrm{N} / \mathrm{L}$, while, the fresh water end-member had 10 $\mu \mathrm{mol}-\mathrm{Si} / \mathrm{L}$ and $<1 \mu \mathrm{mol}-\mathrm{N} / \mathrm{L}$. Chlorophyll content was low $(0.5 \mu \mathrm{g} \mathrm{Chl}-\mathrm{a} / \mathrm{L})$ in the low-salinity Alaskan Coastal Waters. Across the remainder of the strait, chlorophyll concentrations averaged about $1 \mu \mathrm{g}$-chl/L, but concentrations ranged up to 8 $\mu \mathrm{g}-\mathrm{chl} / \mathrm{L}$ in the Anadyr water north of the Strait.

Twenty five days later (day 271), the conditions within the Bering Strait had changed dramatically (Fig. 6). Salty waters (salinities $>32$ and sigma-t values $>25.6 \mathrm{~kg} / \mathrm{m}^{3}$ ) were found across the entire U.S. portion of the Strait and were separated by a sharp frontal boundary from warmer fresher waters $\left(4-5.5^{\circ} \mathrm{C}\right.$, salinities of $\left.30.6-31.7,24.4-25.0 \mathrm{~kg} / \mathrm{m}^{3}\right)$ in the upper half of the water column north of the Strait (CTD 180-188). The T-S diagram of these transects showed that the saltier end-member of each transect was nearly the same and represented Anadyr Water (Fig. 7). Also, silicate and nitrate plus nitrite concentrations of the Anadyr water were identical between the two sampling times $(38 \mu \mathrm{mol}-\mathrm{Si} / \mathrm{L}$ and $18 \mu \mathrm{mol}-\mathrm{N} / \mathrm{L})$. The fresh water end-member found on the early and late section differed considerably; the later section had waters which were cooler and saltier than the earlier Alaskan coastal end-member. Also, in this latter period, this end-member had much greater nutrient concentrations, $24 \mu$ mol-Si $/ \mathrm{L}$ and $4 \mu \mathrm{mol}-\mathrm{N} / \mathrm{L}$. In the second Bering Strait sampling, chlorophyll concentrations generally ranged between $1-2 \mu \mathrm{g} / \mathrm{L}$, so that the patch of high chlorophyll water north of the Strait was gone. Altogether, the temperature, salinity, and nutrients found on day 271 indicated that the fresh water end-member was central Chukchi water or Siberian shelf water rather than water from the Alaska Coastal Current. The condition, where waters characteristic of Anadyr Water are found on the eastern shore of the Bering Strait and Chukchi Waters occur just north of the Strait and infringing upon the western CTD station, is anomalous. Based on previously studied hydrographic patterns ([2], see discussion), this hydrographic data suggested the occurrence of a flow reversal (southward flow) in the western parts of the Bering Strait. We note that during the final time that the ship was in the Bering Strait area, shipboard winds were blowing south with gusts greater than $10 \mathrm{~m} / \mathrm{s}$. 
DISTANCE - km
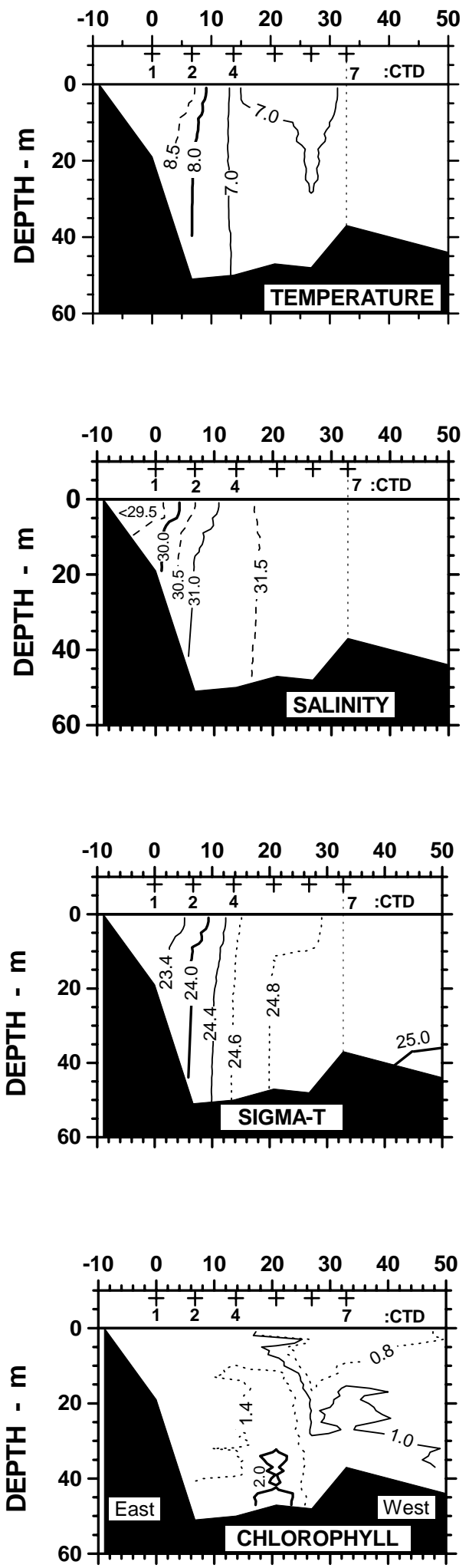
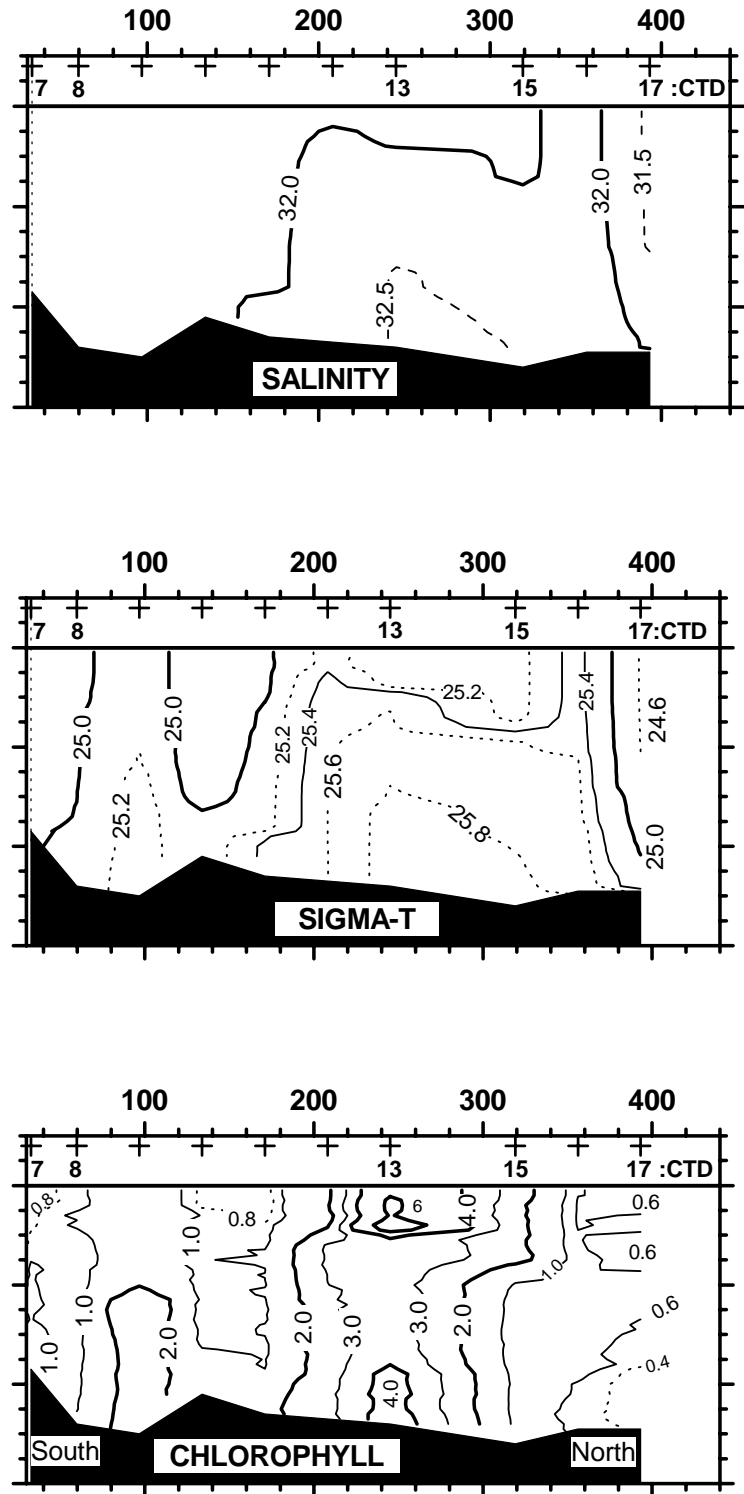

Fig. (5). Sections of temperature, salinity, sigma-t, and chlorophyll ( $\mu$ g-chl/L) in the Bering Strait and along the U.S.-Russian border on Julian days 244-246 (August 31-September 2). Panels on the left are of stations in the Strait oriented approximately westwardly. Panels on the right are stations along the Russian-U.S. boundary line oriented northerly. 

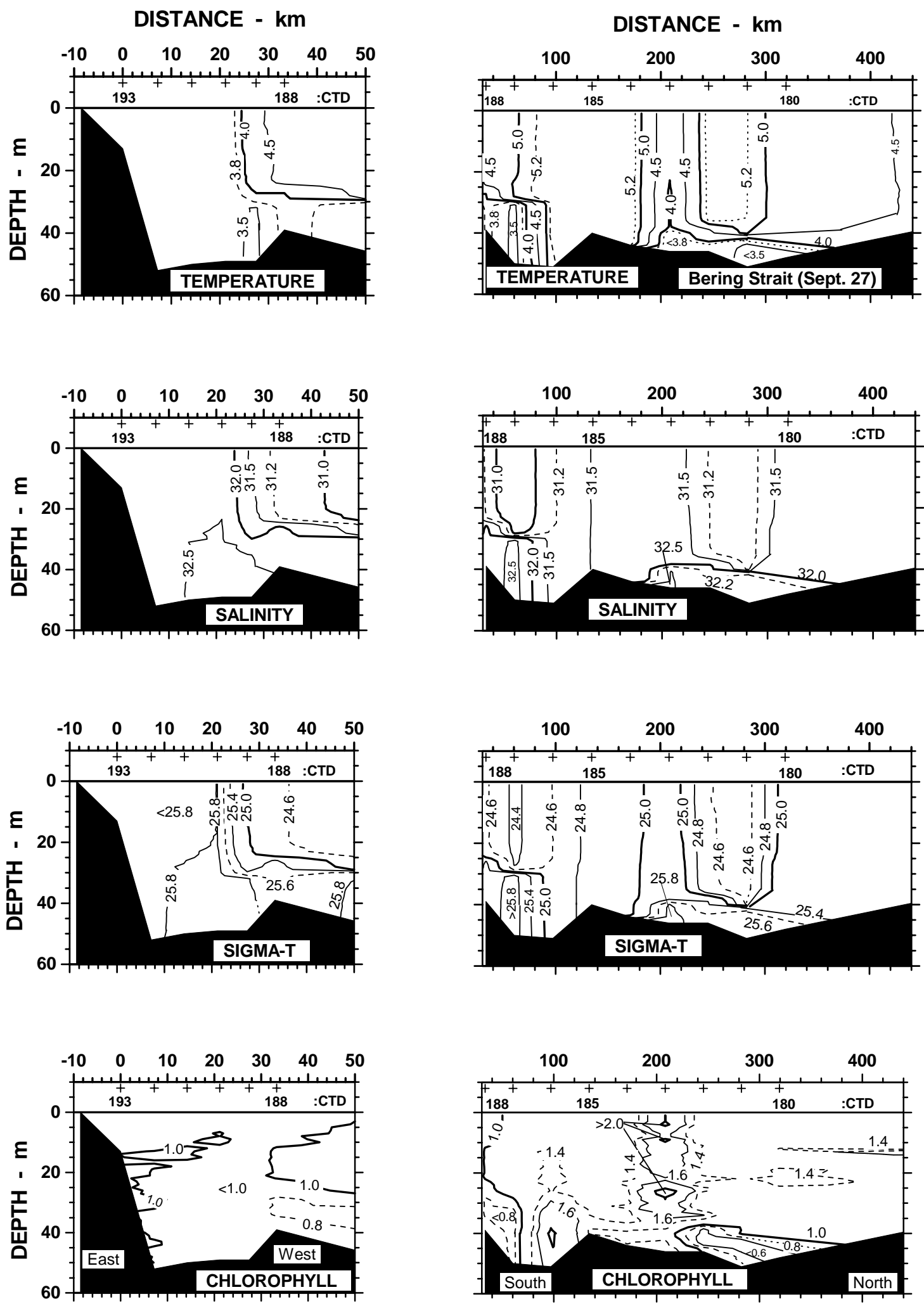

Fig. (6). Sections of temperature, salinity, sigma-t, and chlorophyll ( $\mu \mathrm{g}$-chl/L) in the Bering Strait and along the U.S.- Russian border on Julian day 271 (27 September). Panels on the left are of stations in the Strait oriented approximately westwardly. Panels on the right are stations along the Russian-U.S. boundary line oriented northerly. 


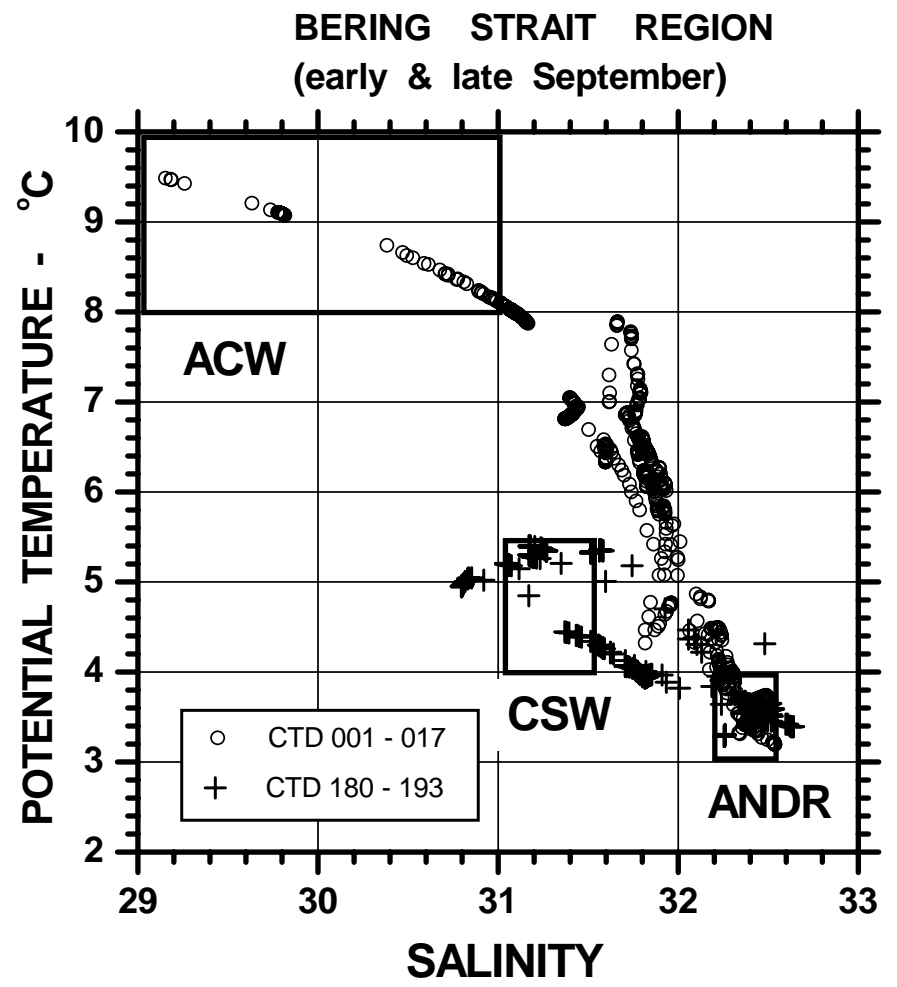

Fig. (7). Relationship of potential temperature to salinity for stations near the Bering Strait in early and late September. Alaskan coastal waters (box marked ACW) were waters with temperatures of $8-10^{\circ} \mathrm{C}$ and salinities of $29-31$ and represented the northward flowing coastal waters impacted by the Yukon River. Anadyr Waters (box marked ANDR) were those with temperatures of 3-4 ${ }^{\circ} \mathrm{C}$ and salinities of $32.3-32.7$. Chukchi Sea Waters were those with temperatures of $4-5.6^{\circ} \mathrm{C}$ and salinities of 31.0-31.6.
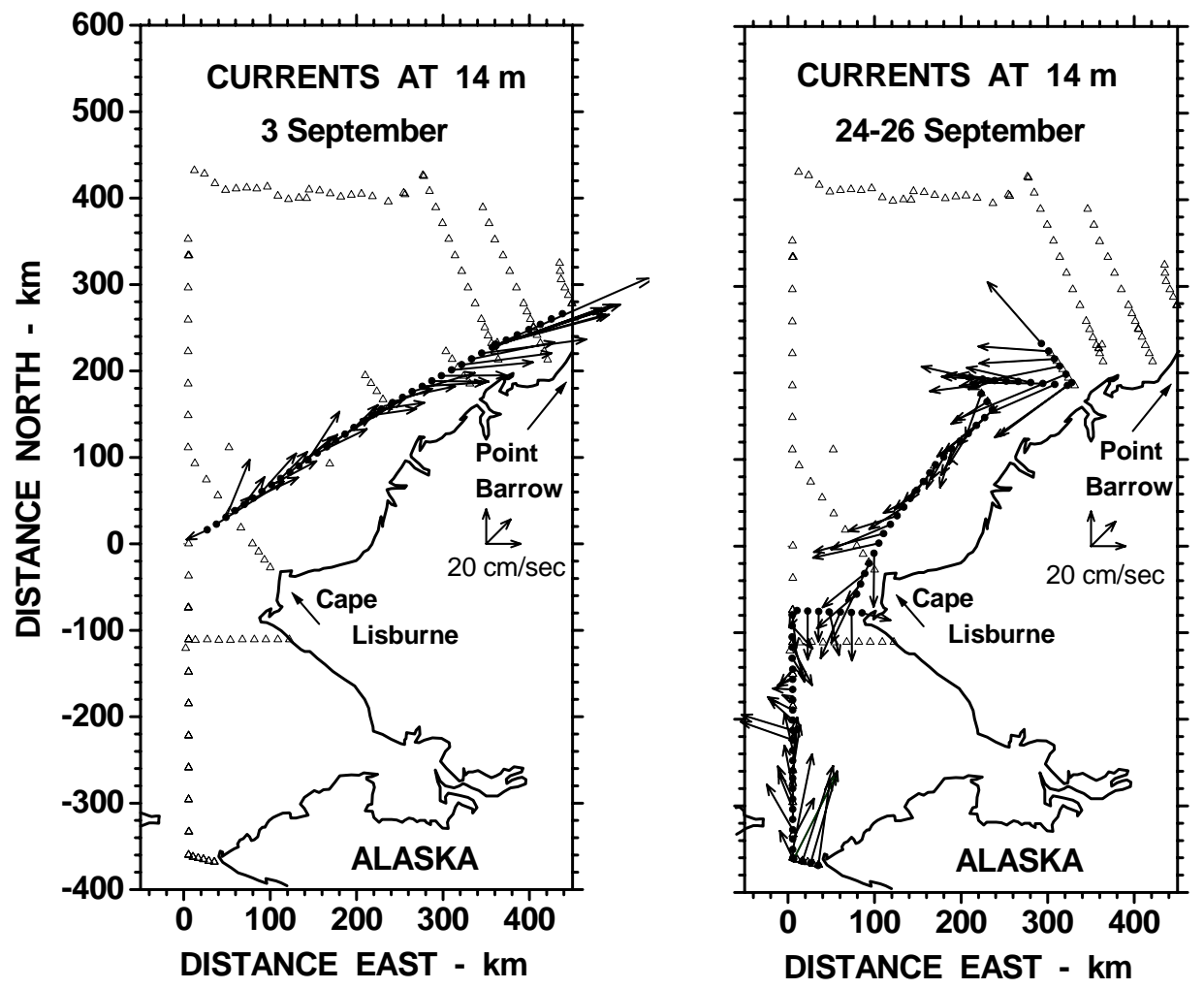

Fig. (8). ADCP current vectors at $14 \mathrm{~m}$ from two transits between Cape Lisburne and the Barrow region from Julian day 247 (September 3 , Left Panel) and on days 268-270 (September 24-26, Right Panel). Every twentieth datum was plotted. 

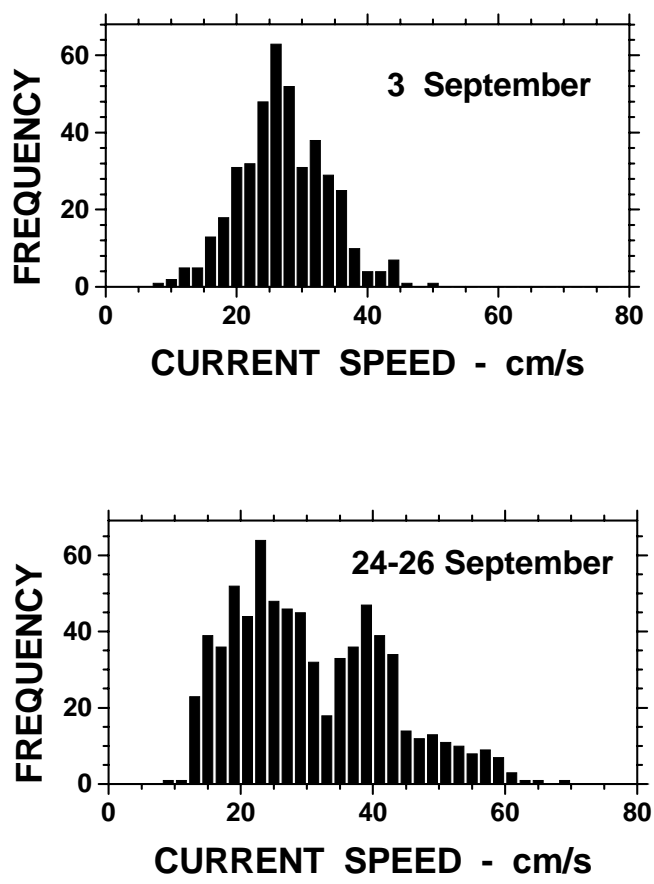
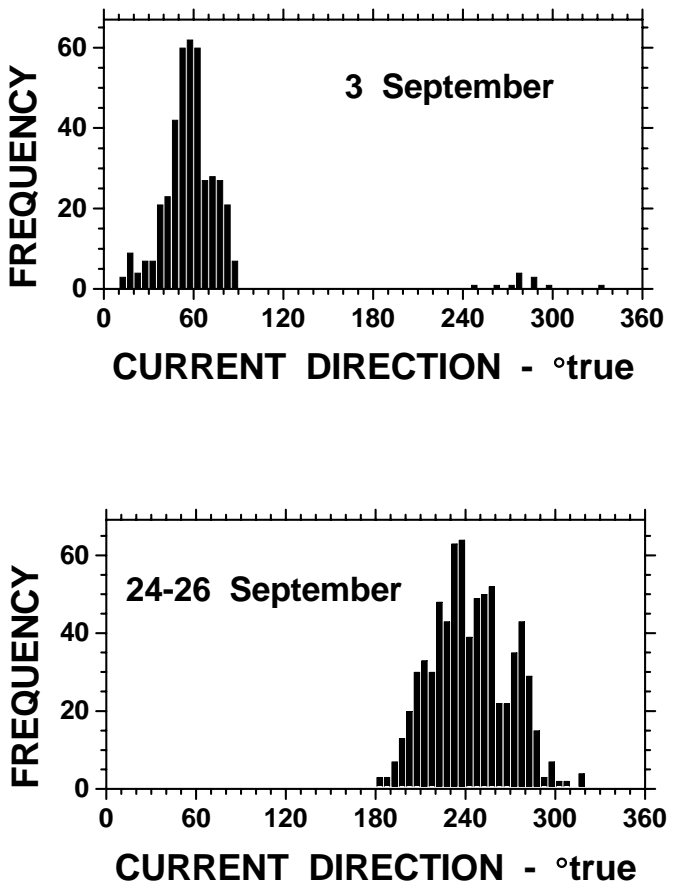

Fig. (9). Histograms of current speed and current direction for the ADCP current data measured on the Cape Lisburne to Point Barrow transits on Julian day 247 (top two panels) and 268-270 (bottom two panels).

\section{Currents between Cape Lisburne and Point Barrow}

Currents along the coastline from Cape Lisburne to Point Barrow, assessed via shipboard ADCP measurements, changed markedly between the beginning and end of the shipboard operations. Early in the cruise (day 247), nearsurface flows (14 m depth) were strongly northeastward in the Alaskan Coastal Current (Fig. 8 left), the typical condition of the Chukchi Sea. However, by the end of the cruise (day 268-270), the currents near the coast were directed southwesterly (Fig. 8 right) in opposite direction to the expected flow of the Alaskan Coast Current. Tidal velocities were not subtracted from these ADCP results. Maximal tidal currents are less than $10 \mathrm{~cm} / \mathrm{s}$ throughout most of the Chukchi Sea [31,32], with many investigators reporting tides less than $5 \mathrm{~cm} / \mathrm{s}[35,36]$. During both of our ship transits, the ADCP record lasted more than a tidal cycle, $>16$ hours in transit on day 247 and $>29$ hours on days 268-270. Histograms of the current data from the region between Cape Lisburne and Barrow (Fig. 9) show that nearly all of the ADCP observations had current speeds greater than $10 \mathrm{~cm} / \mathrm{s}$ with the majority of data having speeds greater than $25 \mathrm{~cm} / \mathrm{s}$ (Fig. 9 left). Thus, the observed data would be altered only slightly by tidal correction. Also, the histogram of northeastward current speed in early September (Fig. 8 top) indicates normal velocities of the Alaska Coastal Current [11, 37-39]. The important point is that in early September, our observations show typical flow of the Alaska Coastal Current (Fig. 8 left, 9 top); while, in the later part of September, the Alaska Coastal Current was flowing toward the southwest (Fig. 8 right, 9 bottom). Thus, during this expedition, the additional characteristic of strong autumn winds, that of reversal of the Alaskan Coastal Current, was observed. We now present the upwelling conditions found along the northern continental shelf break.

\section{Barrow Canyon Region}

The northeastern region of the Chukchi Sea, including Barrow Canyon, was sampled on several transects between days 250 and 270 (Fig. 1) and showed the presence of several different types of waters. We note that types of waters of the central and northern Chukchi Sea differ somewhat with geographical area due to the seasonal changes in source water conditions within the Bering Strait and differential climatological impacts during the long transit time across the Chukchi shelf [15, 34]. Nevertheless, we found waters lying over much of the central and northeastern part of the Chukchi Sea to be moderately uniform, with much of the water having temperatures of $>4^{\circ} \mathrm{C}$ and salinities between 31 and 32. During this time, Chukchi Sea waters had low concentrations of nutrient and chlorophyll. Dissolved silicate and nitrate plus nitrite concentrations were $<5 \mu \mathrm{mol} / \mathrm{L}$ and $<2 \mu$ $\mathrm{mol} / \mathrm{L}$, respectively. Chlorophyll concentrations over much of the shelf were about $1 \mu \mathrm{g}$-chl/L, but near the northern shelf edge were typically lower, around $0.5 \mu \mathrm{g}$-chl/L. However, at some stations, primarily associated with Barrow Canyon in the northeast, high concentrations of nutrients (up to $50 \mu \mathrm{mol}-\mathrm{Si} / \mathrm{L}$ and $20 \mu \mathrm{mol}-\mathrm{N} / \mathrm{L}$ ) were observed at much shallower depths than offshore, which we detail below.

We contrast these characteristics with those offshore waters from the Canada Basin (transect line N, Fig. 1). Water types on the T-S diagram (Fig. 10) for the offshore Canada Basin included the Arctic Surface Water $\left(<0^{\circ} \mathrm{C}\right.$, salinities $<31.0)$, Upper Halocline Water $\left(<-1.0^{\circ} \mathrm{C}\right.$, salinities of 32.7 33.0), Lower Halocline Water $\left(0\right.$ to $-1.0^{\circ} \mathrm{C}, 34.4$ salinity), and Atlantic Water (about $1{ }^{\circ} \mathrm{C}, 34.7$ salinity). Water types along the northeastern transect line $\mathrm{N}$ (Fig. 10) were at their typical depths in the Canada Basin [1, 40], e.g. the Upper and Lower Halocline Waters were found between 100-160 m and $160-220 \mathrm{~m}$ respectively. Within the northeastern shelf 


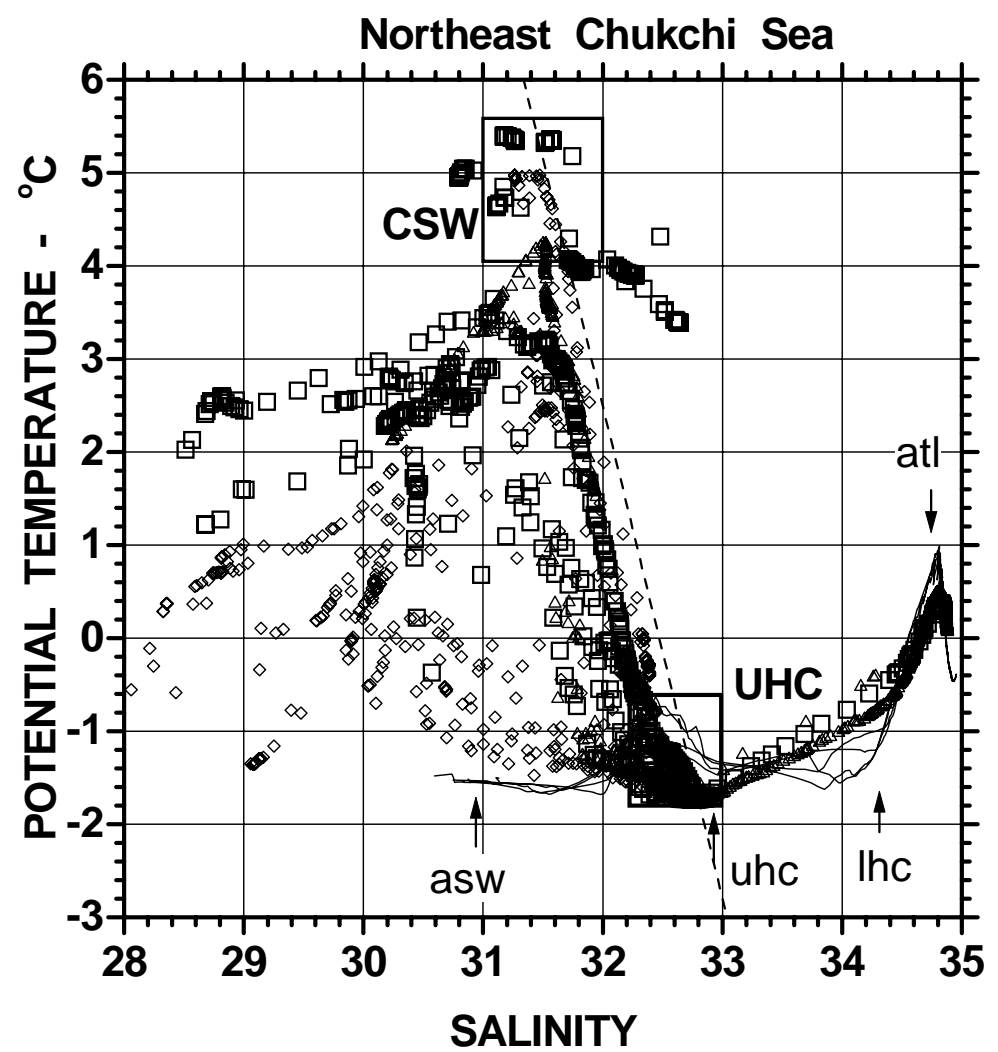

Fig. (10). Relationship of potential temperature to salinity for the northeastern Chukchi Sea. The thin solid lines represent offshore waters (stations 8-11 on the Arctic Ocean Section cruise [40]). The thick solid line represent offshore waters on this cruise (CTD 25). Positions of traditional offshore Arctic water types are shown with arrows (asw is Arctic Surface Water, uhc is Upper Halocline water, lhc is Lower Halocline water, and atl is Atlantic water). Solid circles represent data from the Bering Strait region (CTDs 180-193). Hollow squares, triangles and diamonds represent data from transect lines $\mathrm{La}, \mathrm{Kb}$, and $\mathrm{I}$. The data fall in an approximate triangular relationship indicating the presence of three end-member water types. The right-hand apex of the triangle represents the Upper Halocline water (box marked UHC) with potential temperatures of -0.5 to $-1.7^{\circ} \mathrm{C}$ and salinities of $32.2-32.8$. The Chukchi water type (marked CSW) is $4.0-5.6^{\circ} \mathrm{C}$ and salinities of 31.0-31.6.

region, the T-S diagram showed a triangular relationship (Fig. 10) where the lower right-hand end-member was the Upper Halocline Waters and the upper apex reflected the general conditions in the Chukchi Sea centered at $4.5^{\circ} \mathrm{C}$ and 31.5 salinity (box CSW, Fig. 10). The left-hand portion of the T-S triangle represented fresher waters with salinities as low as 28 but with considerable variation in temperature $\left(-1.5\right.$ to $3^{\circ} \mathrm{C}$, Fig. 10). For waters with salinities less than 32.8 , one of the strongest relationships was the apparent linear relationship between upper halocline waters and general Chukchi Sea waters (indicated by the data parallel to and just to the left of the dashed line connecting the CSW and UHC boxes, Fig. 10), indicating strong mixing between these two water types.

Sections across Barrow Canyon showed a shoaling of the higher salinity waters from deeper offshore. For example, on the coastal (southern) side of transect J, warm fresher waters (the Alaska Coastal Current) were found to depths of $40 \mathrm{~m}$ south of a surface frontal boundary between CTD 116 and 117 (Fig. 11). To the north of this frontal boundary were fresh cold waters $\left(<1^{\circ} \mathrm{C}\right.$, salinities $\left.<30,<25.0 \mathrm{~kg} / \mathrm{m}^{3}\right)$ to depths of about $20 \mathrm{~m}$. A strong pycnocline separated these surface waters from cold salty waters which filled most of Barrow Canyon and over-rode the northern wall of the canyon to depths as shallow as $30 \mathrm{~m}$. These cold saltier waters $\left(<-1.0^{\circ} \mathrm{C}\right.$, salinities $\left.>32.5,>25.8 \mathrm{~kg} / \mathrm{m}^{3}\right)$ fit the $\mathrm{T}-\mathrm{S}$ character- istics of the UHC box, which were found offshore at depths of $100 \mathrm{~m}$ or more (Line N). Thus, the section of Line J demonstrated the occurrence of upwelling of the offshore waters onto the shelf, corresponding to another characteristic of the windier season.

In the offshore areas, the upper halocline waters have a characteristic high nutrient content, reaching $50 \mu \mathrm{mol}-\mathrm{Si} / \mathrm{L}$ and $20 \mu \mathrm{mol}-\mathrm{N} / \mathrm{L}$ (Fig. 12 top). Although the number of nutrient samples were insufficient to map the on-shelf nutrient distributions, individual station profiles showed that the occurrence of high salinity waters (32.5 and greater) defined the presence of nutrient concentrations $>18 \mu \mathrm{mol}-\mathrm{Si} / \mathrm{L}$ and $>8 \mu \mathrm{mol}-\mathrm{N} / \mathrm{L}$ (Fig. 12 bottom). A graph of silicate and nitrate plus nitrite versus salinity (Fig. 13) showed that the highest nutrients correlated with salinities of about 32.8. In the figure, some of these higher values were the offshore stations at water depths greater than $200 \mathrm{~m}$. However, the high nutrient samples (silicate $>18 \mu \mathrm{mol} / \mathrm{L}$ and nitrate plus nitrite $>8 \mu \mathrm{mol} / \mathrm{L})$ found at shallow stations $(<200 \mathrm{~m})$ were associated with salinities of 32.5 or higher (Fig. 13). Samples with salinities less than 32 had silicate concentrations $<8 \mu$ $\mathrm{mol} / \mathrm{L}$ and nitrate plus nitrite concentrations less than $<2 \mu$ $\mathrm{mol} / \mathrm{L}$, reflecting the depauperate nutrient condition of northern Chukchi Sea waters. This demonstrates that the source of high nutrient waters on the northeastern Chukchi shelf was the upwelled Upper Halocline Water. 


\section{LINE J - DISTANCE - km}
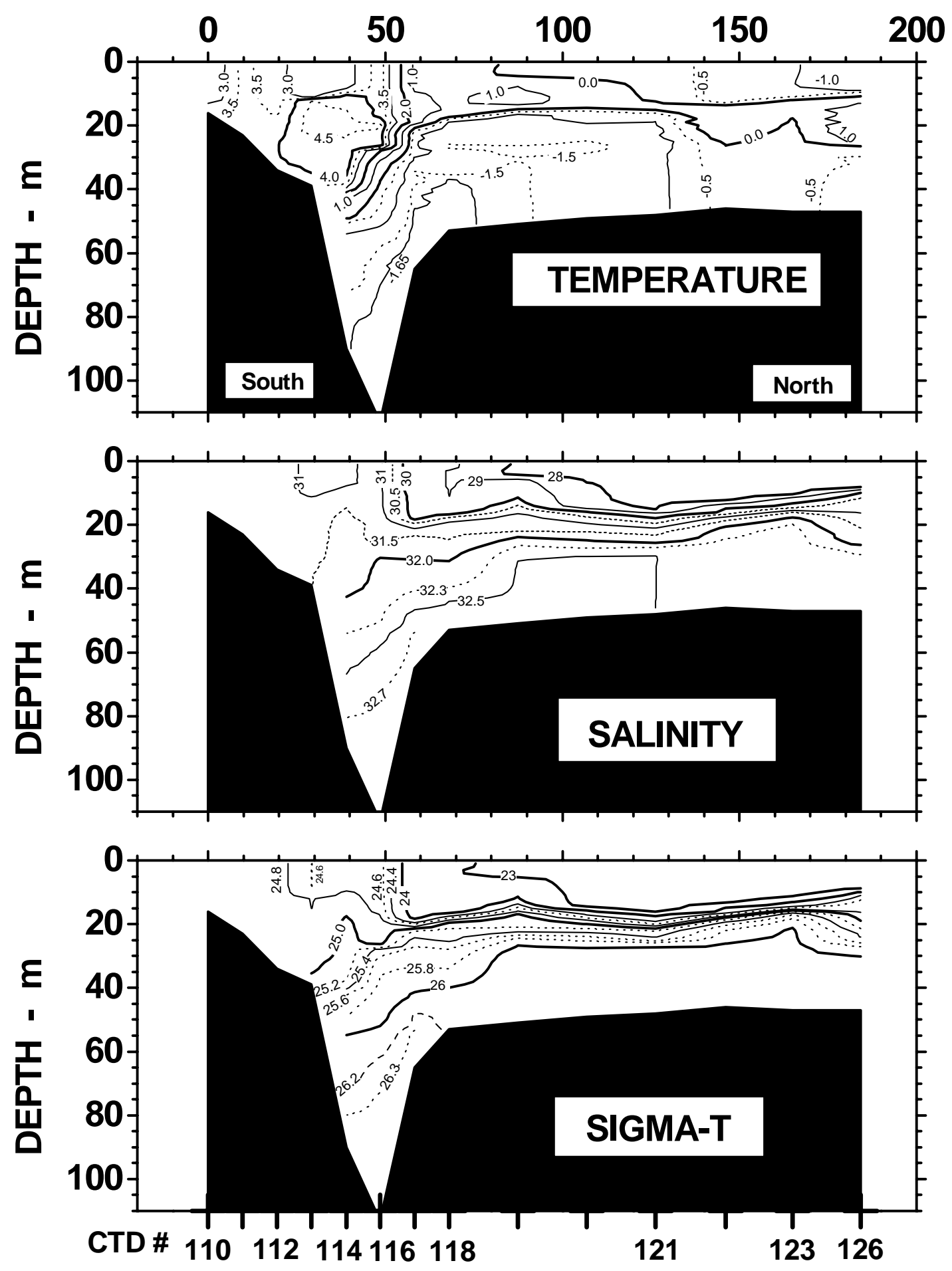

Fig. (11). Sections of temperature, salinity, and sigma-t along transect Line-J across Barrow Canyon.

The upwelling we observed appeared to be large in scale and to have occurred in the period of time during which we were sampling. In the first sampling near the Canyon's mouth on days 249-251, the 32.5 isohaline contour on Line M domed by $90 \mathrm{~m}$ from the south side of the Canyon (120 m) to the most offshore site on the transect (depth of about
$30 \mathrm{~m}$, Fig. 14 top). Where the UHC waters reached the euphotic zone, the chlorophyll section (not shown) showed a strata of high concentrations exceeding $1 \mu \mathrm{g} / \mathrm{L}$ and occasionally exceeding $4 \mu \mathrm{g} / \mathrm{L}$ at depths of $25-35 \mathrm{~m}$. Thus, these UHC nutrients had been at this shallow depth long enough for the algal community to respond by growth. However, our 

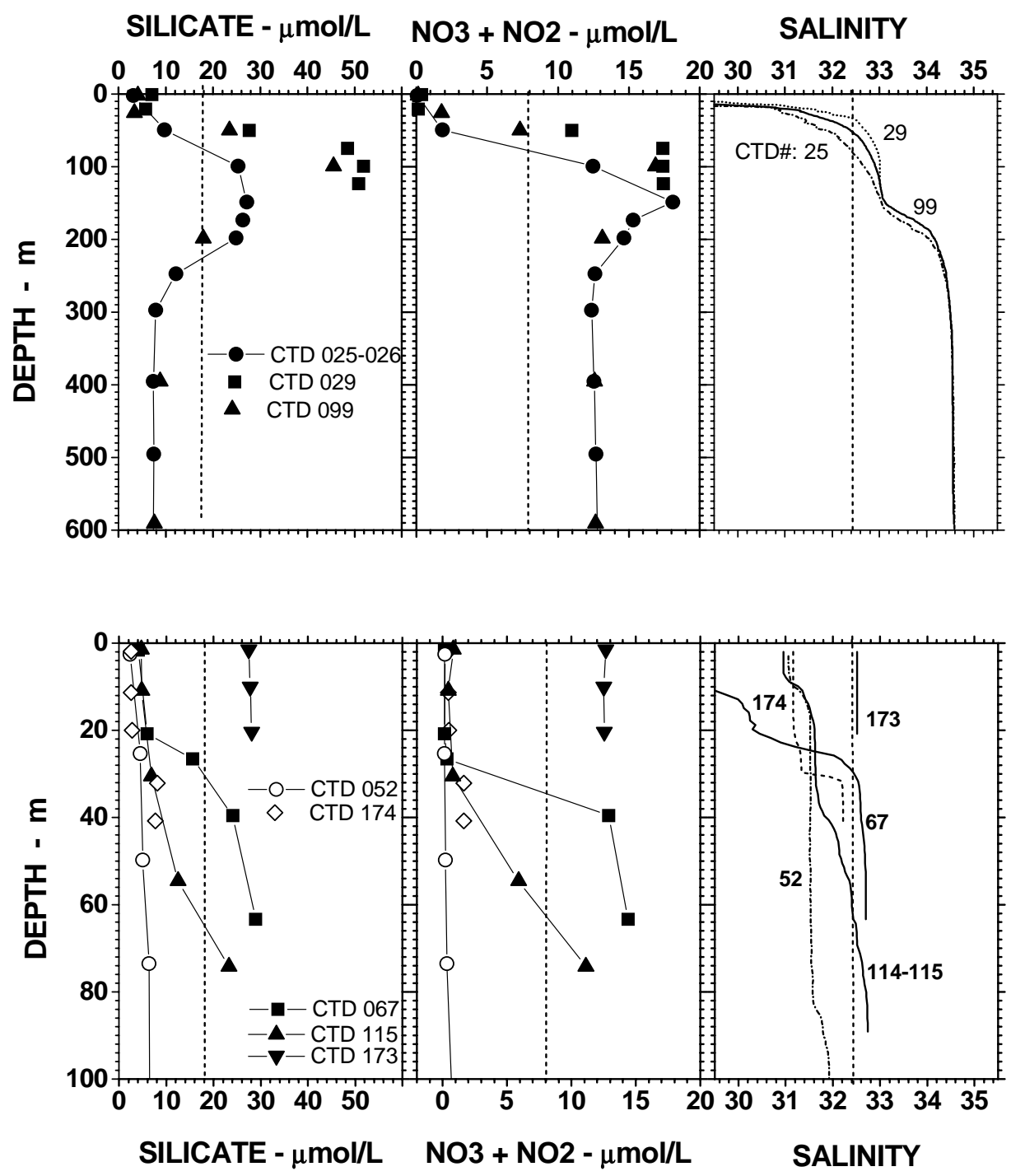

Fig. (12). Vertical profiles of silicate, nitrate plus nitrite, and salinity. TOP: Profiles of silicate, nitrate plus nitrite, and salinity in offshore CTDs (CTDs 25, 26, 29, and 99). Maximum nutrient concentrations were found in the halocline layers centered at about 100-150 m. BOTTOM: Profiles of silicate, nitrate and nitrite, and salinity at selected shelf stations where no high salinity water was found (stations 52 and $174)$ or where high salinity waters had penetrated $(67,115,173)$. Enriched nutrient concentrations were solely associated with the halocline waters (salinities greater than 32.5). Vertical dotted lines mark the separation between shelf and halocline concentrations.

data from this early period showed that the shallow 32.5 isohaline had not extended far into the Canyon. Transect line La showed significant doming, but the shallowest depth was 55 $\mathrm{m}$. No corresponding increase in chlorophyll occurred on this line, indicating that upwelling on this line was too deep to affect the euphotic zone. Station 28, on the shelf north of Barrow Canyon, showed the 32.5 isoline at $51 \mathrm{~m}$. However, other stations within the Canyon (line Ka and stations 18 and 19) lacked any salinities as high as 32.5 . Thus, at this time, the upwelling was restricted to a dome near the Canyon mouth.

The arrival of severe storms drove the research vessel southward, but when the vessel returned, UHC salinities were found over much of the shelf plateau north of Barrow Canyon (Fig. 14 bottom). At many sites, the 32.5 salinities were found within the upper $30 \mathrm{~m}$. Chlorophyll sections of lines $\mathrm{J}, \mathrm{Kb}$, and $\mathrm{Lb}$ showed a rich chlorophyll band near the bottom of the euphotic zone and just above the UHC waters
(Fig. 15). The most southern transect, Line G, showed the classical structure of wind driven coastal upwelling with 40 $\mathrm{m}$ bottom water at the offshore stations being drawn in toward shore and upwelled to the surface (not shown), but salinities never exceeded 32.2 and nutrients were low. Unlike Line $\mathrm{G}$, the near-shore stations along Line $\mathrm{H}$ had nearly vertical isohaline lines of UHC water and uniformly high nutrient concentrations (Fig. 16). The currents at $14 \mathrm{~m}$ (Fig. 8) indicated that nearshore flow was southwestward, parallel to the coast. These data suggested that UHC waters were being driven along the coast as a vertical slug, with little time for lateral mixing. Chlorophyll concentrations on Line $\mathrm{H}$ were low suggesting that the arrival of the high nutrients to the surface waters had not yet stimulated algal growth (Fig. 16). Thus, the hydrographic, nutrient, and chlorophyll data suggest a canyon upwelling event which started about day 250 or soon thereafter and which expanded over the next 18 days. 

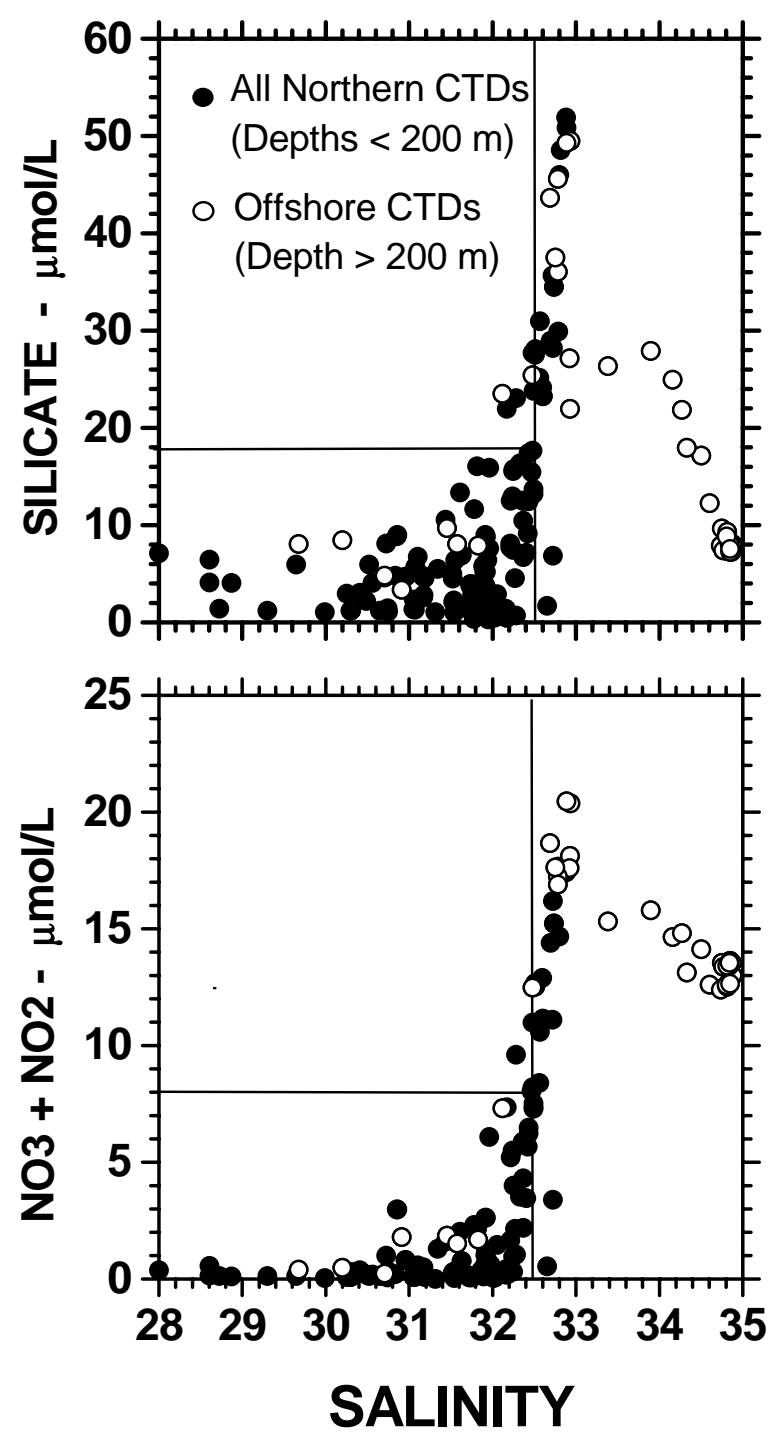

Fig. (13). Relationship of silicate to salinity (top) and nitrate plus nitrite to salinity (bottom) for all stations north of Cape Lisburne. Open circles are offshore stations (bottom depths $>200 \mathrm{~m}$ ), and dark circles are shelf stations $(<200 \mathrm{~m})$. Highest nutrient concentrations occurred at a salinity of 32.8. All shelf waters with salinities less than 31 had low nutrient concentrations $(<10 \mu \mathrm{mol}-\mathrm{Si} / \mathrm{L}$ and $<2$ $\mu \mathrm{mol}-\mathrm{N} / \mathrm{L})$. Horizontal and vertical lines mark the salinity of 32.5 , and concentrations of $18 \mu \mathrm{mol}-\mathrm{Si} / \mathrm{L}$, and $8 \mu \mathrm{mol}-\mathrm{N} / \mathrm{L}$ which are used to characterize upper halocline waters.

Our chlorophyll concentrations are similar to other latesummer measurements $[13,14,26]$, but unlike most other studies, our station grid was sufficiently close-spaced to show the details of the association of plant pigments with the upwelling plume. The chlorophyll sections (Fig 15) showed patches of high chlorophyll concentrations which rivaled the high concentrations found in the first Bering Strait sampling. On line $\mathrm{J}$, the maximum exceeded $6 \mu \mathrm{g}$-chl/L; while on lines $\mathrm{Kb}$ and $\mathrm{Lb}$, these exceeded 2.4 and $5.0 \mu \mathrm{g}$-chl/L. These subsurface chlorophyll bands parallel the depth of the 32.5 and 32.0 isohaline lines, but at the offshore section ( $\mathrm{Lb})$, the chlorophyll band is at a greater distance above the 32.5 isohaline (c.a. $25 \mathrm{~m}$ ) than at the inshore sections $(5 \mathrm{~m}$ on line $\mathrm{J})$. The differences in the vertical distance above the 32.5 iso- haline reflect the differences in the vertical nitrate gradient $\left(\mathrm{dNO}_{3}{ }^{-} / \mathrm{dz}\right)$. The nitrate concentrations just below the depth of the chlorophyll maximum appear similar (2-4 $\mu \mathrm{mol} / \mathrm{L})$ but the nitrate gradient is much steeper inshore relative to the Canyon mouth, a likely result of both convergence of the isohaline lines and continued nutrient removal by plants as the waters are forced inshore. At the southern terminus of the plume, Line $\mathrm{H}$, where high salinity waters form a vertically uniform slug at the inshore stations, no chlorophyll has yet been produced. On this particular transect, nutrient profiles measured on the two end stations (CTDs 169 and 173) were approximately conservative with salinity. So nitrate plus nitrite concentrations were regressed onto salinity, and the resulting regression used to construct profiles of estimated nitrate plus nitrate at all stations on the transect. From these profiles, we constructed a section of estimated nitrate plus nitrite (Fig. 16 bottom), which showed that nitrogen concentrations of $12-15 \mu \mathrm{mol} / \mathrm{L}$ were located from the sea surface to the seafloor on the inner portion of this transect. Chlorophyll-a concentrations were less than $0.6 \mu \mathrm{g} / \mathrm{L}$ throughout nearly all of the section, and the majority of the volume had less than $0.4 \mu \mathrm{g} / \mathrm{L}$. Given phytoplankton particulate nitrogen with a ratio of $0.6 \mu \mathrm{mol}-\mathrm{PN} / \mu \mathrm{g}$-chl $[41,42]$, the chlorophyll content seen in this section would amount to $0.36 \mu \mathrm{mol}-\mathrm{N} / \mathrm{L}$ or less, and would represent only a minor nitrogen reservoir relative to the estimated nitrate plus nitrite. Given that all this nitrate will be incorporated into phytoplankton particulate nitrogen, this nutrient content would convert to $25 \mu \mathrm{g}$ chl/L throughout the entire euphotic zone, without grazing or sinking loses [24, 43]. These results indicate that upwelling of the high nitrate waters onto the shelf could have dramatic affects on productivity.

\section{DISCUSSION}

The Bering Strait inflow to the Arctic Ocean, resulting primarily from a downward sea surface slope (to the north) due to the mean density difference between the North Pacific Ocean and the Arctic Ocean $[16,38]$ is affected by the winds and their seasonality. Local winds near Bering Strait in summer (April - August) are weaker and from the south; while winds in autumn are stronger, more variable, and from the north [2]. Strong north winds oppose the normal sea water flow through the Strait, and various investigators have found that flow reversals occur when northerly winds reach about $8 \mathrm{~m} / \mathrm{s}$ [2, 15-18]. The regional wind pattern also influences the Bering Strait flow by shifting the ocean currents just south of the Strait from a northerly course to an eastwest heading $[2,18]$. Given the differences in the two seasons, flow reversals are infrequent events during summer $(0-$ $5 \%$ of the days) but are more common in the fall (9-34\% of the days [2]).

Our results during September 1996 showed that conditions in the Bering Strait shifted from typical northerly flow in early September to those that mimic a partial flow reversal as the weather in late September deteriorated. In our initial sampling of the Bering Strait, the coastal waters were found on the eastern portion of the channel and were characterized by salinities less than 31 and temperatures of nearly $9^{\circ} \mathrm{C}$. Nitrate plus nitrite concentrations were $0-1 \mu \mathrm{mol} / \mathrm{L}$, silicate concentrations were generally $11-15 \mu \mathrm{mol} / \mathrm{L}$, and chlorophyll concentrations were generally low $(<0.5 \mu \mathrm{g}-\mathrm{chl} / \mathrm{L})$. The least diluted form of Anadyr water was found to the 

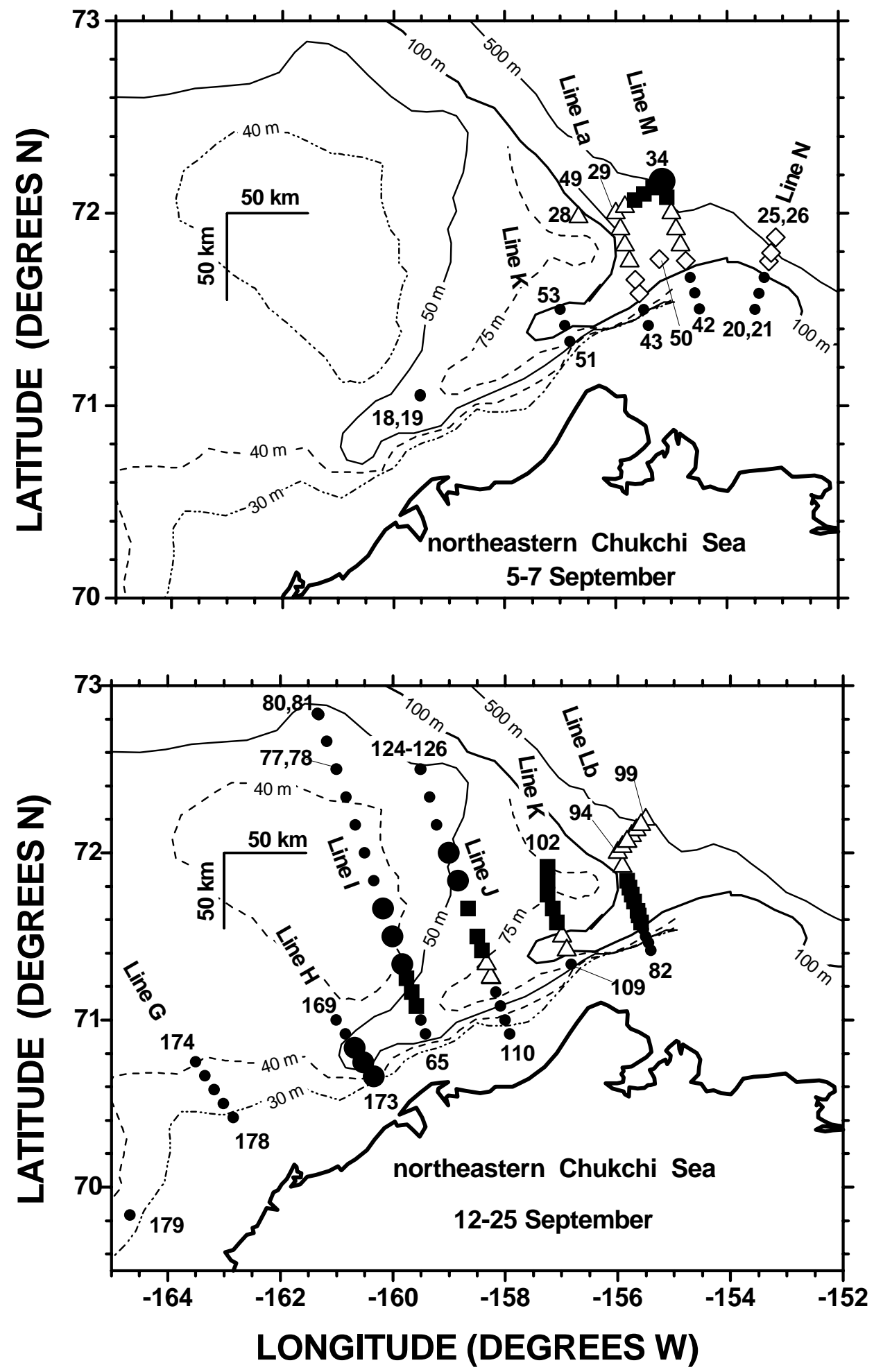

Fig. (14). Shallowest depth of waters with salinities of 32.5 (Upper Halocline waters) in two time periods within the Barrow region. Small dark circles indicate stations within the time period of the panel where all salinities were less than 32.5. Stations where the shallowest appearance of high salinity waters was at or below $90 \mathrm{~m}$ depth were represented by open diamonds, between 50 and $90 \mathrm{~m}$ depth (open triangles), between 30-50 m (dark squares), or shallower than $30 \mathrm{~m}$ depth (large dark circles).

north of the Strait and had characteristic T, S, nitrate plus nitrite, and silicate characteristics of $3.5^{\circ} \mathrm{C}, 32.4,15 \mu \mathrm{mol}-$ $\mathrm{N} / \mathrm{L}$, and $40 \mu \mathrm{mol}-\mathrm{Si} / \mathrm{L}$, respectively, and chlorophyll concentrations that ranged up to $8 \mu \mathrm{g}$-chl/L. This corresponds to the typical distribution of waters within the Strait under northward flow conditions. At the end of the cruise twenty five days later, the conditions within the Strait differed. Anadyr water $\left(3.5^{\circ} \mathrm{C}\right.$ and 32.4 salinity) was found filling the 

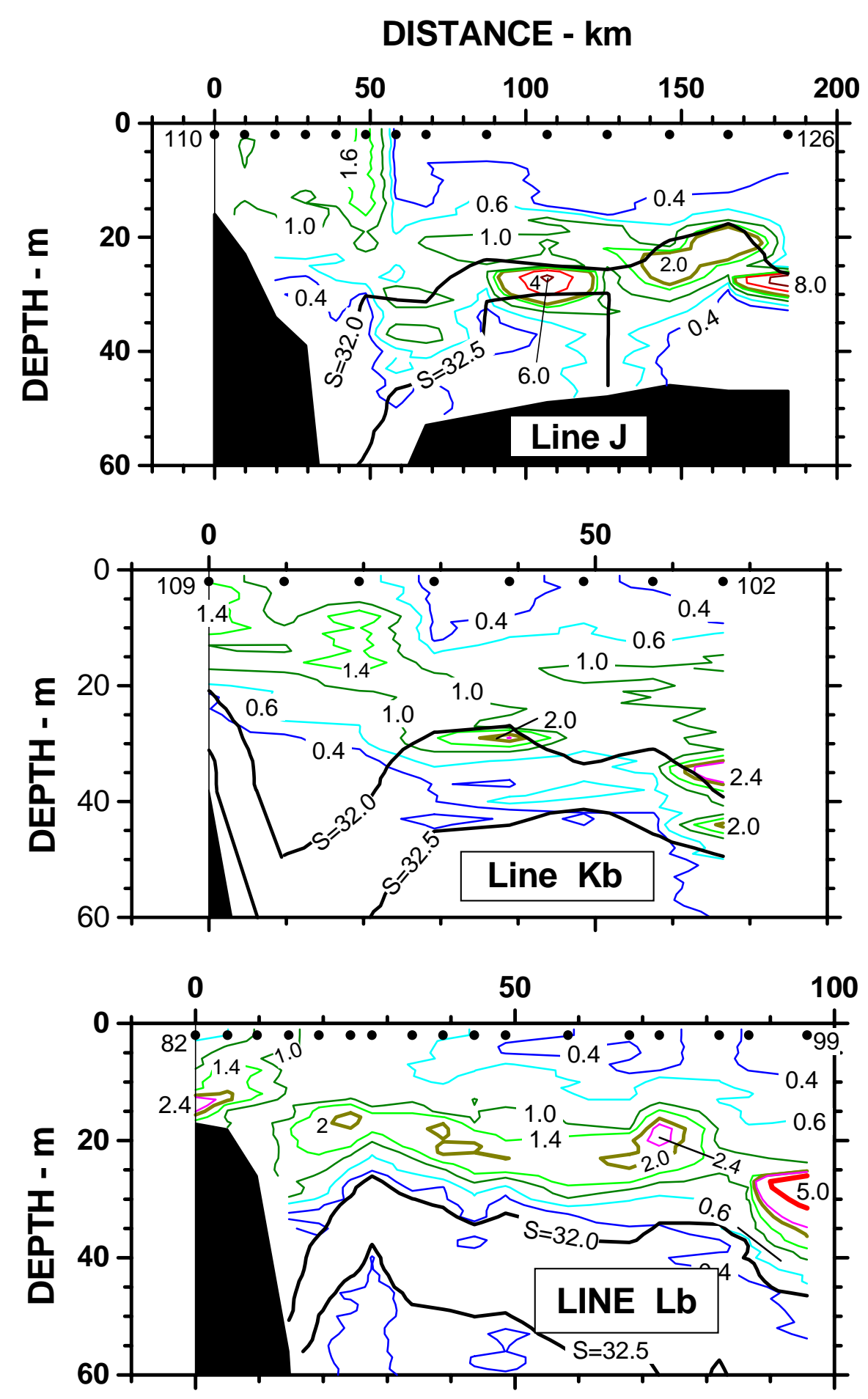

Fig. (15). Vertical sections of chlorophyll concentrations ( $\mu \mathrm{g}$-chl/L) across Barrow Canyon. The dark lines are 32.5 and 32.0 isohaline contours. Station locations are marked by small solid circles with the beginning and end CTD number.

eastern portion of the Strait, and the river-influenced freshwater end member, found in the Strait in early September, was not present. Winds over the latter part of the cruise were directed southward and were strong with episodes greater than $10 \mathrm{~m} / \mathrm{s}$. The wind intensity was sufficient so that waters from the north (off Cape Lisburne) were flowing toward the Bering Strait. This situation represents the third pattern of flow reversal as defined by Coachman [2]. In this pattern, waters on the Russian side of the Strait move southward, while in the Chirikov Basin to the south of the Bering Strait, newly upwelled Anadyr waters are forced eastward toward Norton Sound, resulting in a counter-clockwise gyre centered within Bering Strait.

The second result of the seasonal change in wind intensity and direction is occasional reversal in the flow of the Alaskan Coastal Current. Several studies have examined the 
correlation of current meter records with local winds as a cause for reversal of the Alaskan Coastal Current and for upwelling in Barrow Canyon. Little correlation of current records with springtime with local winds were found [37], which may have resulted from the ice-pack shielding the surface waters from the local winds. Based on another data set from October 1986 - August 1987, wind variability at Point Barrow has been found to explain only $25 \%$ of the low-frequency current variance in Barrow Canyon, with the wind leading the current by 6-12 hours [36]. In contrast, year-long current meter records from moorings between the
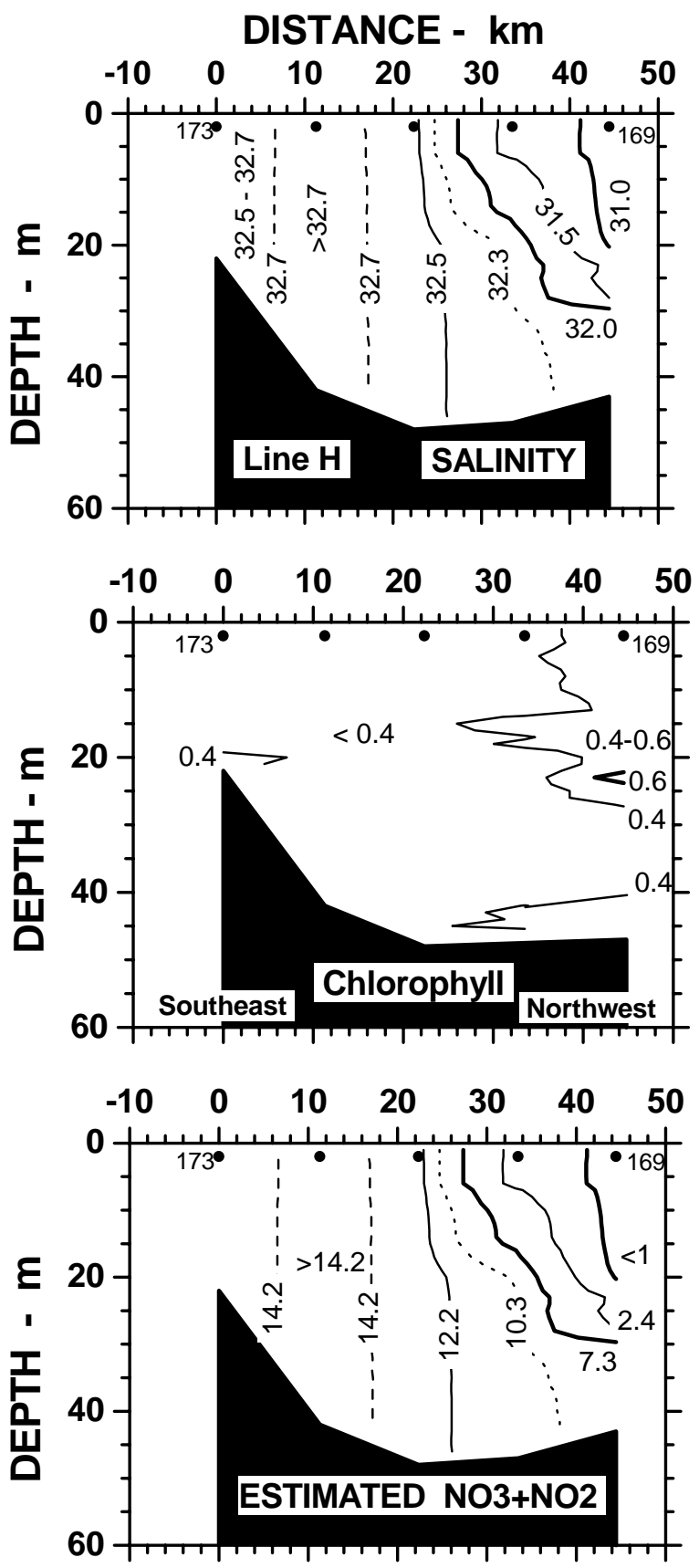

Fig. (16). Vertical sections of salinity, chlorophyll ( $\mu \mathrm{g} / \mathrm{L})$, and estimated nitrate plus nitrite $(\mu \mathrm{mol} / \mathrm{L})$ along transect $\mathrm{H}$. Estimated nitrate plus nitrite concentrations were evaluated as described in the text. Station locations are marked by small solid circles with the beginning and end CTD number.
Bering Strait and Barrow Canyon deployed between September 1991 and September 1992, showed that local winds were coherent with Barrow Canyon flows $62 \%$ of the time with the winds leading the currents by 18 hours [11]. As to the difference between these two years (1986-7 and 1991-2), the earlier period was characterized by wind variance of twice that of the 1991-1992 period, and that increased wind variance would lessen the degree of correlation [11].

We found that the Alaskan Coastal Current had reversed during late September. We showed that the climatological winds are supportive of southeastern flow of waters along the Cape Lisburne to Point Barrow coastline and these winds would potentially drive strong upwelling at all times of the year. The autumn windy period is particularly strong, with winds averaging $5.29 \mathrm{~m} / \mathrm{s}$ and the Bakun index averaging $0.18 \mathrm{~m}^{3} \mathrm{~s}^{-1}$ ( $\mathrm{m}$ of coastline) $)^{-1}$. The coast from Barrow to Cape Lisburne is $450 \mathrm{~km}$ long, so this average Bakun index would indicate an offshore flow of near-surface water from the coast of $0.084 \mathrm{~Sv}$. This wind-driven flow would act in opposition to the northward sea-surface pressure gradient. In 1991-2, reversals of the Alaska Coastal Current consistently occurred when alongshore wind speeds exceeded $5.9 \mathrm{~m} / \mathrm{s}$ [11]. Accepting this critical velocity, the climatological winds during the autumn windy period $(5.29 \mathrm{~m} / \mathrm{s})$ would diminish but not block the northward flowing Alaskan Coastal Ccurrent. We showed that 1996 was a year with high autumnal winds relative to the previous 35 years. During the time we occupied the northern Chukchi Sea, the late September windy period (Julian days 259-272) had frequent extreme winds, exceeding $10 \mathrm{~m} / \mathrm{s}$. During this late September period, we found strong southward surface flow along the coast from Cape Lisburne to Point Barrow. Over this period, the average upwelling index was $0.53 \mathrm{~m}^{3} \mathrm{~s}^{-1} \mathrm{~m}^{-1}$, which would translate into coastal upwelling of $0.24 \mathrm{~Sv}$.

North of Cape Lisburne, the composition of Chukchi Sea waters appeared to be characterized by mixing between three end-members. The typical Chukchi Sea end-member had a temperature of about $4.5^{\circ} \mathrm{C}$ and salinities of $31-32$. Nutrient concentrations were low, averaging $5 \mu \mathrm{mol}-\mathrm{Si} / \mathrm{L}$ and $1-2 \mu$ mol-N/L, while chlorophyll concentrations averaged about 1 $\mu \mathrm{g}$-chl/L. A second end-member consisted of fresher colder waters from several sources which had similarly low nutrient and chlorophyll concentrations. The third end-member was Upper Halocline Water, which in our deep casts had as much as $50 \mu \mathrm{mol}-\mathrm{Si} / \mathrm{L}, 20 \mu \mathrm{mol}-\mathrm{N} / \mathrm{L}$, and no measurable pigment fluorescence. On the shelf, high nutrient concentrations were those carried by these cold salty waters. Chlorophyll concentrations in these waters were generally very low, but strong algal growth occurred soon after these waters entered the euphotic zone or were positioned at the interface just below the euphotic zone. Since upper halocline waters are thought to be formed in winter on the shelf, it is possible that these occurrences could be residual brine-enriched eddies retained on the shelf from the previous winter [42, 44, 45]. However, given the shallowness of this shelf, one would expect wintertime shelf waters to have experienced summer-time algal growth if they had remained on the shelf for the entire spring and summer. As a result of this growth, patches of wintertime shelf water would be subjected to differing degrees of nutrient depletion. Our observations show that high nutrients were solely found in waters with higher salinities, and near Barrow, these high salinity waters were contiguous with off- 
shore deeper halocline layers. Thus, our results are easier to explain based on upwelling from offshore rather than by retention of winter waters on the shelf.

We observed a large upwelling event associated with Barrow Canyon where upper halocline waters filled much of the western Canyon, overflowed the northern shelf area, and covered much of the northeastern Chukchi. Our event appears similar to that observed by Johnson [20] in late August 1986. In 1986, winds from the east-northeast, at speeds of up to $4.2 \mathrm{~m} / \mathrm{s}$, reversed the flow of the Alaskan coast current for 3 days and apparently promoted the influx of low temperature $\left(<-1^{\circ} \mathrm{C}\right)$, higher salinity $(>32.8)$ waters normally found at depth. Similarly, Bourke and Paquette [46] found a nearbottom warm saline layer which reached depths of less than $40 \mathrm{~m}$ and which covered a large area of the northeastern Chukchi Sea. Garrison and Paquette [47] showed that upwelled waters reached depths of 40-50 m near the head of Barrow Canyon. Thus, volumetrically large upwelling events have been frequently noted in this area which is infrequently sampled. In our event, we estimated the volume of upwelled waters to be $300 \times 10^{9} \mathrm{~m}^{3}$ based on the maximum area $(12 \mathrm{x}$ $10^{9} \mathrm{~m}^{2}$ ) covered by salinities exceeding 32.5, and an average thickness of $25 \mathrm{~m}$ above either the $75 \mathrm{~m}$ depth or the sediments (if shallower than $75 \mathrm{~m}$ ). Assuming that this plume began moving up the Canyon on or about Julian day 250, after our first sampling of the outer portion of the Canyon, and reached the size that we mapped by the end of our Barrow sampling on day 268 , the average transport rate over these 18 days would have been $0.19 \mathrm{~Sv}$.

The coherence of winds with upwelling in Barrow Canyon which was described earlier suggests that upwelling along the coast from Cape Lisburne to Barrow Canyon may have an important role influencing the deeper upwelling through the Canyon. However, the causes for upwelling within Barrow Canyon may be multiple, and regional-scale processes also may play a role. Mountain et al. [37] found that $55 \%$ of the spring-summer Barrow Canyon flows could be explained by the Barrow-Nome air pressure difference. Aagaard and Roach [36] found that close coherence of currents, temperature, and salinity between moorings within Barrow Canyon and ones placed at $100 \mathrm{~km}$ and $400 \mathrm{~km}$ east of the canyon mouth on the Beaufort slope. The propagation speed of these coherent events was $2.3 \mathrm{~m} / \mathrm{s}$, which they attribute to eastward moving shelf waves. In this view, current reversals would occur as these shelf waves pass by the mouth of Barrow Canyon. Furthermore, the fall winter intensification of these events may result from the greater atmospheric kinetic energy and a correspondingly higher shelf wave energy level. Munchow and Carmack [21] suggested that the uplifting of halocline waters by $100-150 \mathrm{~m}$ in the outer portion of Barrow Canyon (Sept. 1993) would have resulted from a narrow westward flowing surface current located about $40 \mathrm{~km}$ north of the shelf break and this current could perhaps be part of a baroclinic anticyclonic eddy near the mouth of the canyon. Signorini et al. [48] found that nonlinear interaction between the variable barotropic flow with the steep topography is the primary mechanism for bringing deeper Canada Basin water up into the shallower canyon. On a larger scale, they suggest that barotropic variability of the Bering Strait volume transport communicates transport variability to Barrow Canyon via a topographic wave, which within the deeper portions of the canyon is transformed to
Kelvin wave propagation. Weingartner et al. [11, 34] suggested that windy periods from late fall through early winter would have regional affects causing a weakening and partial reversal of the Alaskan Coastal Current, upwelling in the region around Barrow and a diversion of Bering Strait flows to the west toward Siberia (our results are similar).

In late September 1996, once the UHC waters were shallow enough and neared the shore, our data indicated rapid southwestward transport of the UHC along the shallow coast as a homogeneous volume. Consequently, in this later period, strong coastal upwelling acted to transport the shallow UHC waters along the coast and within the euphotic zone. At these shallow depths, this plume of high nutrient water would have developed extensive algal blooms well south of Barrow Canyon.

The importance of this shelf-edge upwelling can be demonstrated by comparing this event with the dominant flow in the region, through Bering Strait. The average flow through Bering Strait is $0.8 \mathrm{~Sv}$ (Table 1) which compares with the estimated average flow of our Barrow plume (0.19 $\mathrm{Sv})$. Thus, considering a time period of 18 days, the Barrow Canyon upwelling represent a volumetric inflow of water of $24 \%$ of the average through the Bering Strait (Table 1). Since the upwelling waters are extremely cold and nutrient rich, the heat loss and nutrient addition to the shelf from this plume was enhanced over that for volume, representing $59 \%, 58 \%$ and $41 \%$ of the average inputs of heat, nitrate plus nitrite, and silicate through the Bering Strait for an 18 day time period (Table $\mathbf{1}$ ).

It could be argued that these upwelling events lack longterm significance because the upwelled waters would be fully swept back out of the Canyon as soon as the wind intensity or direction shifted. If so, the event would have no net impact on the Chukchi Sea composition. However, we argue that our estimate represents a minimum for two reasons. First, the observed plume overflowed onto the shelf and allowed mixing with shelf waters, as demonstrated by the triangular mixing region within the T-S diagrams from the northern transects. Our estimate was a minimum one since it did not include these mixed water types. Secondly, the shallow intrusions of nutrient-rich cold waters stimulated significant algal growth as indicated by the occurrence of chlorophyll rich bands located at the interface between these slope waters and the ambient shelf waters. We note that our station grid was sufficiently close-spaced to show details of the association of plant pigments with the upwelling plume. Summer-time measurements in the Arctic have shown that maximum ${ }^{14} \mathrm{C}$-based primary productivities are found in these deep chlorophyll layers just above the nutricline [14, $26,43]$. Because the upwelling occurred near the end of the growth season, bacterial and herbivorous consumers are readily available to graze the new blooms [24, 43], potentially keeping the chlorophyll abundance lower than would be found during typical ungrazed spring blooms. The net affect of this upwelling was stimulated new production which would enrich the organic matter supply both to the planktonic consumers and to the benthos below. Thus, these onshore upwelling events may have an important impact on ecosystem productivity in this relatively oligotrophic region. With continuing change of the Arctic climate, it is likely that winds will increase and sea-ice extent will decrease [49]. 
Table 1. Estimated Transports in the Barrow Upwelling Plume of September 1996 Compared with Average Transports of Volume $\left(10^{6} \mathrm{~m}^{3} / \mathrm{s}\right)$, Heat $\left(10^{9} \mathrm{kcal} / \mathrm{s}\right)$, Salt $\left(10^{6} \mathrm{~kg} / \mathrm{s}\right)$, Nitrate Plus Nitrite $\left(10^{3} \mathrm{~mol} / \mathrm{s}\right)$, and Silicate $\left(10^{3} \mathrm{~mol} / \mathrm{s}\right)$ through the Bering Strait

\begin{tabular}{|c|c|c|c|c|c|}
\hline $\begin{array}{l}\text { Location, } \\
\text { Reference }\end{array}$ & $\begin{array}{l}\text { Volume } \\
\text { Flow }\end{array}$ & $\begin{array}{l}\text { Heat } \\
\text { Flow }\end{array}$ & $\begin{array}{r}\text { Salt } \\
\text { Flow }\end{array}$ & $\begin{array}{c}\mathrm{NO}_{3+} \\
\mathrm{NO}_{2} \text { Flow }\end{array}$ & $\begin{array}{c}\text { Silicate } \\
\text { Flow }\end{array}$ \\
\hline Barrow Canyon ${ }^{\mathrm{a}}$ : & 0.19 & -0.29 & 6.33 & 3.4 & 7.6 \\
\hline$\%$ of Bering Strait Average & $24 \%$ & $-59 \%$ & $25 \%$ & $58 \%$ & $41 \%$ \\
\hline \multicolumn{6}{|l|}{ Bering Strait: } \\
\hline \multicolumn{6}{|l|}{ Aagaard and Greisman [50] } \\
\hline original estimate ${ }^{\mathrm{b}}$ : & 1.5 & 0.9 & 48.6 & -- & -- \\
\hline at present flow ${ }^{\mathrm{e}}$ : & 0.8 & 0.48 & 25.9 & -- & -- \\
\hline \multicolumn{6}{|l|}{ Anderson et al. [51] } \\
\hline original estimate ${ }^{c}$ : & 1.35 & -- & 43.2 & $10.0^{\mathrm{d}}$ & 31.1 \\
\hline at present flow ${ }^{\mathrm{e}}$ : & 0.8 & -- & 25.6 & $5.9^{\mathrm{d}}$ & 18.4 \\
\hline Average of Strait ${ }^{\mathrm{f}}$ : & 0.8 & 0.48 & 25.8 & $5.9^{\mathrm{d}}$ & 18.4 \\
\hline
\end{tabular}

(a) The averages of temperature, salinity, and concentrations of nitrate plus nitrite and silicate were $-1.5^{\circ} \mathrm{C}, 32.5,18 \mu \mathrm{mol}-\mathrm{N} / \mathrm{L}$, and $40 \mu \mathrm{mol}-\mathrm{Si} / \mathrm{L}$. Heat capacity, density, and the reference temperature follow b. (b) The averages of temperature and salinity were $0.5^{\circ} \mathrm{C}$ and 32.4 . Heat capacity was $1 \mathrm{kcal}\left({ }^{\circ} \mathrm{C} \mathrm{L}\right)^{-1}$ and temperature was referenced to mean of $-0.1^{\circ}$ C. Density was $1000 \mathrm{~kg} / \mathrm{m}^{3}$. (c) The averages of salinity and silicate concentration were 31.2 and $23 \mu \mathrm{mol}-\mathrm{Si} / \mathrm{L}$. Density was $1025 \mathrm{~kg} / \mathrm{m}^{3}$. (d) Nitrate was not calculated by Anderson et al. [51], so we assumed the same volume flow and $8 \mu \mathrm{mol}-\mathrm{N} / \mathrm{L}$. (e) Present day volumetric flow rates through the Bering Strait were from [3]. Literature values of the fluxes were reduced proportionally. (f) Average of present flows.

Both trends will expose the northern Alaskan shelf to increased upwelling and shelf-break transport events, and following the pattern we saw, would likely stimulate productivity on the northern shelf and would support a richer marine ecosystem.

\section{CONCLUSIONS}

Based on weather data from Point Barrow, we show that autumn of 1996 was windier than most of the previous 35 years. We sampled the U.S. portion of the Chukchi Sea in September 1996 with 200 CTD casts and shipboard ADCP current measurements. In late September, we found that conditions in the Bering Strait were anomalous in that fresh coastal water was absent from the Strait and a partial flow reversal appeared to be occurring. In the central Chukchi Sea, the northeastward flow of the Alaskan Coastal Current was reversed. In the northern Chukchi Sea, upwelling of offshore upper halocline waters (salinities >32.5) was observed within the Barrow Canyon, with much of the shelf west and south of the Canyon inundated. Dispersion of the plume was enhanced by wind-driven Ekman transport along the northwest Alaska coastline at upwelling rates of 0.24 Sverdurp. The upper halocline waters which were upwelled in the Barrow region contained high concentrations of silicate $(>20 \mu \mathrm{mol}-\mathrm{Si} / \mathrm{L})$ and nitrate plus nitrite $(>8 \mu \mathrm{mol}-\mathrm{N} / \mathrm{L})$, in contrast to typical concentrations of $<8 \mu \mathrm{mol}-\mathrm{Si} / \mathrm{L}$ and $<2$ $\mu \mathrm{mol}-\mathrm{N} / \mathrm{L}$ in the northern Chukchi Sea waters. This plume reached the euphotic zone, and elevated concentrations of chlorophyll (>4 $\mu \mathrm{g}$-chl/L in many places) were found at the interface between Chukchi Sea water and upper halocline water. We estimated an upwelling transport of $0.19 \mathrm{~Sv}$ of upper halocline water in the plume. When compared to the average flow through the Bering Strait; this event equaled
$24 \%$ of the volume flux, $-59 \%$ of the heat flux, and $58 \%$ and $41 \%$ of the nitrate and nitrite and silicate fluxes through the Strait for an equal duration of time. These estimates would be a minimum because mixing of shelf and upper halocline waters were not included. The chlorophyll blooms resulting from this nutrient injection indicate dramatically enhanced ecosystem productivity along this northern shelf region. With increasing climatic change occurring in this region, shelf break productivity would likely increase in the future.

\section{ACKNOWLEDGMENTS}

This work was supported by NSF grants 9530774 , 9905947,0125306 and 0125313 to the lead author. This is contribution number 200811 from Bigelow Laboratory for Ocean Sciences.

\section{REFERENCES}

[1] Coachman LK, Aagaard K. In: Herman Y, Ed. Physical oceanography of arctic and subarctic seas. Marine geology and oceanography of the Arctic Seas. Springer Verlag Publishing, New York, 1974; 172 .

[2] Coachman LK. On the flow field in the Chirikov Basin. Cont Shelf Res 1993; 13: 481-508.

[3] Roach AT, Aagaard K, Pease CH, et al. Direct measurements of transport and water properties through the Bering Strait. J Geophys Res 1995; 100: 18443-18457.

[4] Sambrotto RN, Goering JJ, McRoy CP. Large yearly production of phytoplankton in the western Bering Strait. Science 1984; 225: 1147-50.

[5] Walsh JJ, McRoy CP, Coachman LK, et al. Carbon and nitrogen cycling within the Bering/Chukchi Seas: Source regions for organic matter effecting AOU demand of the Arctic Ocean. Prog Oceanogr 1989; 22: 279-361.

[6] Cooper LW, Whitledge TE, Grebmeier JM, Weingartner TJ. The nutrient, salinity, and stable oxygen isotope composition of Bering and Chukchi Seas waters in and near the Bering Strait. J Geophys Res 1997; 102: 12563-73. 
[7] Shpaikher AO, Yankina ZS. Formation of anomalies of winter hydrological characteristics of East Siberian and Chukchi seas (translation). Problemy Arktiki i Antarktiki 1969; 31.

[8] Weingartner TJ, Danielson S, Sasaki Y, Pavlov V, Kulakov M. The Siberian Coastal Current: A wind- and bouyancy-forced Arctic coastal current. J Geophys Res 1999; 104 (C12): 29697-713.

[9] Woodgate RA, Aagaard K, Weingartner TJ. A year in the physical oceanography of the Chukchi Sea: Moored measurements from autumn 1990-1991. Deep-Sea Res II 2005; 52: 3116-49.

[10] Pickart RS, Weingartner TJ, Pratt LJ, Zimmermann S, Torres DJ. Flow of winter-transformed Pacific water into the Western Arctic. Deep-Sea Res II 2005; 52: 3175-98.

[11] Weingartner TJ, Cavalieri DJ, Aagaard K, Sasaki Y. Circulation, dense water formation, and outflow on the northeast Chukchi shelf. J Geophys Res 1998; 103: 7647-61.

[12] Hameedi JJ. Aspects of water column primary productivity in Chukchi Sea during summer. Mar Biol 1978; 48: 37-46.

[13] Cota GF, Pomeroy LR, Harrison WG, et al. Nutrients, primary production, and microbial heterotrophy in the southeastern Chukchi Sea: Arctic summer nutrient depletion and heterotrophy. Mar Ecol Prog Ser 1996; 135: 247-58.

[14] Hill V, Cota G. Spatial patterns of primary productivity on the shelf, slope, and basin of the Western Arctic in 2002. Deep-Sea Res II 2005; 52: 3344-54.

[15] Coachman LK, Aagaard K, Tripp RB. Bering Strait: the regional physical oceanography. University Washington Press, Seattle, WA. 1975; pp. 172.

[16] Aagaard K, Roach AT, Schumacher JD. On the wind-driven variability of the flow through Bering Strait. J Geophys Res 1985; 90: 7213-21.

[17] Kozo TL, Torgerson LJ. Geostrophic wind velocity thresholds for Bering Strait current reversal under open water and ice covered conditions. EOS 1986; 67: 1015.

[18] Coachman LK, Aagaard K. Transport through Bering Strait: annual and interannual variability. J Geophys Res 1988; 93: 15535-9.

[19] Aagaard K. Features of the physical oceanography of the Chukchi Sea in the autumn. M.S. Thesis, Univ. Wash. Seattle, WA. 1964; p. 41.

[20] Johnson WR. Current response to wind in the Chukchi Sea: a regional coastal upwelling event. J Geophys Res 1989; 94: 20572064.

[21] Munchow A, Carmack EC. Synoptic flow and density observations near an Arctic shelf break. J Phys Oceanogr 1997; 27: 1402-19.

[22] Hufford GL. On apparent upwelling in the Southern Beaufort Sea. J Geophys Res 1974; 79: 1305-6.

[23] Mountain DG. In: Reed JC, Sater JE, Eds. Preliminary analysis of Beaufort Shelf circulation in summer. The coast and shelf of the Beaufort Sea. Arctic Institute of North America, Arlington, VA 1974; 27-48.

[24] Ashjian CJ, Gallager SM, Plourde S. Transport of plankton and particles between the Chukchi and Beaufort Seas during summer 2002, described using a Video Plankton Recorder. Deep-Sea Res II 2005; 52: 3259-80.

[25] Dunton KH, Goodall JL, Schonberg SV, Grebmeier JM, Maidment DR. Multi-decadal synthesis of benthic-pelagic coupling in the western arctic: Role of cross-shelf advective processes. Deep-Sea Res II 1996; 52: 3462-77.

[26] Hill V, Cota G, Stockwell D. Spring and summer phytoplankton communities in the Chukchi and Eastern Beaufort Seas. Deep-Sea Res II 2005; 52: 3369-85.

[27] Horner R. In: Barnes P, Schell D, Reimnitz E, Eds. Phytoplankton abundance, chlorophyll a, and primary productivity in the western Beaufort Sea. The Alaskan Beaufort Sea: Ecosystems and Environments. Academic Press Inc, New York, 1984; 295-310.

[28] Bakun A. Coastal upwelling indices, west coast of North America, 1946-1971. NOAA Technical Report NMFS SSRF-671, Seattle WA. 1973; pp. 103.
[29] Christensen JP. Hydrographic sampling of the Chukchi Sea during the R.V. Alpha Helix cruise, HX194, in September 1996. Data report filed with the National Snow and Ice Data Center 2000; pp. 112.

[30] Parsons TR, Maita Y, Lalli CM. A manual of chemical and biological methods for sea-water analysis. Pergamon Press, New York. 1984. pp. 173

[31] Kowalik Z, Proshutinsky AY. Diurnal tides in the Arctic Ocean. J Geophys Res 1993; 98(C9): 16449-68.

[32] Kowalik Z, Proshutinsky AY. In: Johannessen OM, Muench RD, Overland JE, Eds. The Arctic Ocean tides. The Polar Oceans and their Role in shaping the Global Environment. AGU, Washington D.C. $1994 ; 137-58$.

[33] Joyce TM. On In Situ calibration of shipboard ADCPs. Am Meteorol Soc 1989; 6: 169-72.

[34] Weingartner TJ, Aagaard K, Woodgate R, Danielson S, Sasaki Y, Cavalieri D. Circulation on the north central Chukchi Sea shelf. Deep-Sea Res II 2005; 52: 3150-74.

[35] Aagaard K. In: Barnes PW, Reimnitz E, Eds. The Beaufort Undercurrent. The Alaskan Beaufort Sea: Ecosystems and Environments, Academic Press, San Diego CA 1984; 47-71.

[36] Aagaard K, Roach AT. Arctic Ocean-shelf exchange: Measurements in Barrow Canyon. J Geophys Res 1990; 95: 18163-75.

[37] Mountain DB, Coachman LK, Aagaard K. On the flow through Barrow Canyon. J Phys Oceanogr 1976; 6: 461-70.

[38] Coachman LK, Aagaard K. In: Hood DW, Calder JA, Eds. Reevaluation of water transports in the vicinity of Bering Strait. The Eastern Bering Sea Shelf: Oceanography and resources. National Oceanic and Atmospheric Administration, Washington D.C. 1981; 1: $95-110$.

[39] Aagaard K. In: Anonomous, Ed. Current, CTD, and pressure measurements in possible dispersal regions of the Chukchi Sea. Outer Continental Shelf Environmental Assessment Program, Final Rep. Princ. Invest. Dept. of Commerce/Dept. Of Interior, Anchorage, Alaska 1988; 57; 255-333.

[40] Swift JH, Jones EP, Aagaard K, et al. Waters of the Makarov and Canada Basins. Deep-Sea Res 1996; 44: 1503-30.

[41] Walsh JJ, Whitledge TE, Barvenik FW, et al. Wind events and food chain dynamics within the New York Bight Limnol Oceanogr 1978; 23: 659-83.

[42] Walsh JJ, Dieterle DA, Maslowski W, et al. A numerical model of seasonal primary production within the Chukchi/Beaufort Seas. Deep-Sea Res II 2005; 52: 3541-76.

[43] Sherr EB, Sherr BF, Wheeler PA, Thompson K. Temporal and spatial variation in stocks of autotrophic and heterotrophic microbes in the upper water column of the central Arctic Ocean. Deep-Sea Res II 2003; 50: 557-71.

[44] Cavalieri DJ, Martin S. The contribution of Alaskan, Siberian, and Canadian coastal polynyas to the cold halocline layer of the Arctic Ocean. J Geophys Res 1994; 99: 18343-62.

[45] Gawarkiewicz G, Chapman DC. A numerical study of dense water formation and transport on a shallow, sloping continental shelf. J Geophys Res 1995; 100: 4489-07.

[46] Bourke RH, Paquette RB. Atlantic water on the Chuykchi shelf. Geophys Res Lett 1976; 3: 629-32.

[47] Garrison GR, Paquette RG. Warm water interactions in Barrow Canyon in winter. J Geophys Res 1982; 87: 5853-9.

[48] Signorini SR, Munchow A, Haidvogel D. Flow dynamics of a wide Arctic canyon. J Geophys Res 1997; 102: 18661-80.

[49] Serreze MC, Walsh JE, Chapin FS III, et al. Observational evidence of recent change in the northern high-latitude environment. Clim Change 2000; 46: 159-207.

[50] Aagaard K, Greisman P. Toward new mass and heat budgets for the Arctic Ocean. J Geophys Res 1975; 80: 3821-7.

[51] Anderson LG, Dyrssen DW, Jones EP, Lowings MG. Inputs and outputs of salt, fresh water, alkalinity, and silica in the Arctic Ocean. Deep-Sea Res 1983; 30: 87-94. 